\title{
PENYUSUNAN TOLOK UKUR PENGELOLAAN PERIKANAN BERKELANJUTAN UNTUK KEARIFAN LOKAL DI DESA ADAT KEDONGANAN PROVINSI BALI
}

\section{The Development of Sustainable Fisheries Management Benchmarker for Local Wisdom in Kedonganan Tradisional Village, Bali}

\author{
Ari Kurniawan, *Darmawan, dan Wawan Oktariza \\ Departemen Pemanfaatan Sumberdaya Perikanan, \\ Fakultas Perikanan dan IImu Kelautan, IPB University \\ Jl. Raya Dramaga Kampus, IPB Dramaga Bogor, 16680 Jawa Barat, Indonesia \\ Diterima tanggal: 23 Juni 2020; Diterima setelah perbaikan: 20 Juni 2021; \\ Disetujui terbit: 25 Juni 2021
}

\begin{abstract}
ABSTRAK
Kearifan lokal dalam pengelolaan sumber daya harus diartikan sebagai praktik yang mampu menjaga keberlanjutan sumber daya tersebut. Sementara itu, dalam pengelolaan berkelanjutan terdapat sejumlah ukuran sehingga keberadaan tolok ukur tentang praktik pengelolaan yang arif menjadi sangat relevan. Penelitian yang dilakukan pada Juni - Juli 2019 ini bertujuan menyusun tolok ukur tingkat kearifan masyarakat dalam mengelola sumber daya ikan. Studi kasus dilakukan pada sebuah praktik pengelolaan yang telah ditetapkan oleh pemerintah sebagai kerifan lokal, yaitu di Desa Adat Kedonganan, Bali. Penyusunan tolok ukur dalam penelitian ini dimulai dengan studi pustaka, yang hasilnya kemudian diuji melalui pendekatan observasi lapang dan wawancara mendalam terhadap narasumber yang dipilih secara purposif. Narasumber tersebut adalah lima orang perangkat prajuru adat dan lima orang perwakilan kelompok nelayan. Hasil penelitian ini adalah satu instrumen tolok ukur yang memiliki dua bagian yaitu: (a) aspek dasar pemikiran (factual knowledge) dan (b) aspek praktik pengelolaan (procedural knowledge). Masing-masing bagian memiliki lima kriteria yaitu: (i) ekosistem dan sumber daya, (ii) perencanaan dan tata kelola, (iii) kelembagaan, (iV)alat tangkap dan teknologi, dan (v) sosial dan ekonomi, di mana setiap kriteria tersebut memiliki indikator dan parameter penilaian tertentu. Hasil uji lapang mengungkap adanya perbedaan tingkat kearifan di antara prajuru adat dengan nelayan. Pada aspek factual knowledge, tingkat kearifan nelayan teridentifikasi kuat pada kriteria 'sosial dan ekonomi', moderat pada 'alat tangkap dan teknologi', dan lemah pada tiga kriteria lainnya. Sementara itu, prajuru desa hanya lemah pada kriteria 'sumber daya dan ekosistem'. Pada aspek procedural knowledge, tidak teridentifikasi perbedaan kearifan; baik prajuru desa maupun nelayan, keduanya cenderung lemah pada kriteria 'ekosistem dan sumber daya' dan 'perencanaan, dan kelembagaan', moderat pada kriteria “alat tangkap' dan tinggi pada kriteria "sosial ekonomi'.
\end{abstract}

Kata Kunci: kearifan lokal; pengetahuan faktual; pengetahuan prosedural; tolok ukur perikanan berkelanjutan; indikator

\section{ABSTRACT}

Local wisdom in resource management must be interpreted as a practice that is able to maintain the sustainability of these resources. Meanwhile, in sustainable management there are a number of measures, which is why the existence of benchmarks on wise management practices is exceptionally relevant. The research, which was conducted in June - July 2019, aimed to compile a benchmark for the level of community wisdom in managing fish resources. The case study was carried out on a fisheries management practice in the Kedonganan Traditional Village of Bali, that has been determined by the government as local wisdom. The study began with a literature study, the results of which were then tested through a field observation approach and in-depth interviews with purposively selected sources. These resource persons are five persons of prajuru adat leaders and five representatives from five fishing groups. The results of this study are a benchmark instrument that has two parts: (a) aspects of the rationale (factual knowledge) and (b) aspects of management practices (procedural knowledge). Each part has five criteria, namely: (i) ecosystem and resources, (ii) planning and governance, (iii) institutional, (iV) fishing gear and technology, and ( $v$ ) social and economic, where each criterion has certain indicators and assessment parameters. Results from the field test revealed that there were differences in the level of wisdom between leaders in prajuru adat and the fishers. On factual knowledge aspect, the level of fisherman's wisdom was identified as strong on the 'social and economic' criteria, moderate on 'fishing gear and technology', and 
weak on the other three criteria. Meanwhile, leaders in prajuru adat is only weak on the criteria of 'resources and ecosystems'. On procedural knowledge aspect, no differences in wisdom level were identified; both prajuru adat and fishers tend to be weak on the criteria of 'ecosystems and resources' and 'planning, and institutions', moderate on the criteria of "fishing gear" and high on the criteria of "socio-economic.

\section{Keywords: local wisdom; factual knowledge; procedural knowledge; sustainable fisheries benchmarks; indicators}

\section{PENDAHULUAN}

Berbagai bentuk pengelolaan sumber daya perikanan berbasis masyarakat di Indonesia dapat ditemukan dalam berbagai nama (Nikijuluw, 1994; Zamani \& Darmawan, 2000; Suharjito, 2003). Keberadaan pengelolaan-pengelolaan tradisonal tersebut diakui secara formal oleh negara melalui berbagai peraturan perundang-undangan. Undang-Undang Dasar (UUD) 1945 pasal 18 (B) ayat 2 menyatakan bahwa: "Negara mengakui dan menghormati kesatuan masyarakat hukum adat beserta hak tradisionalnya sepanjang masih hidup dan sesuai dengan perkembangan masyarakat dan prinsip Negara Kesatuan Republik Indonesia, yang diatur dalam undang-undang". Terkait dengan pengelolaan tradisional, terdapat istilah kearifan lokal, yang tercantum dalam UndangUndang Nomor 31 Tahun 2004 tentang Perikanan Pasal 6 Angka 2. Dalam pasal tersebut disebutkan bahwa: "Pengelolaan perikanan untuk kepentingan penangkapan ikan dan pembudidayaan ikan harus mempertimbangkan hukum adat dan atau kearifan lokal serta memperhatikan peran serta masyarakat'. Hukum adat dan atau kearifan lokal yang dijadikan pertimbangan dalam pengelolaan perikanan adalah (praktik pengelolaan) yang tidak bertentangan dengan hukum nasional. Istilah kearifan lokal muncul lagi pada UndangUndang Nomor 1 Tahun 2014 tentang Perubahan atas Undang-Undang Nomor 27 Tahun 2007 tentang Pengelolaan Wilayah Pesisir dan PulauPulau Kecil dalam Pasal 1 Angka 36. Di dalamnya disebutkan bahwa "Kearifan lokal adalah nilai-nilai luhur yang masih berlaku dalam tata kehidupan masyarakat". Dalam peraturanperaturan perundang-undangan tersebut, bentuk praktik pengelolaan yang tidak bertentangan dengan hukum nasional disini dimaksudkan sebagai praktikyang mengedepankan pencapaian keberlanjutan sumber daya.

Di Kementerian Kelautan dan Perikanan (KKP), istilah kearifan lokal ditegaskan dan digunakan untuk mendeskripsikan praktik masyarakat hukum adat atau tradisional dalam memanfaatkan sumber daya perikanan
Penegasan ini tercermin pada adanya berbagai program yang ditujukan untuk desa-desa atau kelompok masyarakat, yang disebut memiliki kearifan lokal (KKP, 2017). Pengertian yang sama digunakan pula oleh kebanyakan penulis, yang menyebutkaanbahwa praktik pemanfaatan sumber daya perikanan oleh masyarakat tradisional/hukum adat adalah suatu kearifan lokal (Fitrisia, 2014; Naing, Santosa, \& Soemarno, 2009; Puspita, 2008).

Terlepas dari adanya berbagai kesamaan pandang tersebut di atas, ternyata belum ada standar terukur yang dapat digunakan untuk menilai apakah praktik pemanfaatan tersebut memenuhi pengertian arif. Pengertian arif sebagaimana tertuang dalam Kamus Besar Bahasa Indonesia harus diterjemahkan melalui tolok ukur yang baku sehingga dapat dipahami dengan jelas yang diartikan dengan kondisi arif pada tingkatan tertentu. Dalam hal ini, kata arif artinya bijaksana, cerdik dan pandai dalam konteks kemampuan mengelola sumber daya secara keberlanjutan.

Mengacu pada kamus bahasa Inggris, padanan kata 'arif' dalam cambridge dictionary (dictionary.cambridge.org) adalah 'wisdom' yang diartikan sebagai the ability to use knowledge and experience to make good decisions and judgments artinya kemampuan seseorang untuk menggunakan pengetahuan dan pengalamannya untuk membuat serangkaian keputusan atau penilaian yang baik. Definisi kearifan atau wisdom justru banyak diteliti dan dikemukakan dalam ilmu psikologi. Baltes \& Staudinger (2000) dalam Paradigma Kearifan Belin (Berlin Wisdom Paradigm - BWP), mengemukakan beberapa aspek dalam hal mendefinisikan kata 'arif'. Mereka menyampaikan bahwa kata arif mencakup dua aspek utama yaitu: terkait factual knowledge (pengetahuan kondisi faktual) dan terkait procedural knowledge (pengetahuan mengenai hal prosedural). Selain itu, terdapat juga tiga aspek tambahan yaitu: life-span contextualism atau kontekstualisme jangka hidup/jangka panjang, value relativism (relativisme nilai - nilai/dapat diukur), serta recognition and management of uncertainty (pemahaman dan pengelolaan ketidakpastian). 
Oleh sebab itu, pemberian label kearifan lokal pada kelompok masyarakat tanpa didahului oleh pemahaman terhadap dasar dan pola pemikiran serta tindakan masyarakat tersebut perlu ditinjau kembali.

Sebenarnya telah ada upaya-upaya,ke arah pendefinisian kearifan oleh sejumlah pakar, misalnya di bidang psikologi. Salah satu di antaranya adalah Monica Ardelt (2004), yang menyatakan bahwa kearifan harus melekat pada perilaku keseluruhan dari seseorang bukan suatu yang sekedar menjadi pengetahuan atau keahlian tertentu. Kemudian, Gugerell dan Riffert (2012) dalam analisisnya terhadap berbagai definisi kearifan menyimpulkan bahwa kearifan adalah sesuatu yang sangat kompleks sehingga tidak akan mudah diukur. Perkembangan teknik estimasi stok sumber daya ikan juga menggunakan kata arif atau wisdom, namun pengertian tersebut digunakan dalam kondisi ketiadaan data/ informasi tentang pemangku kepentingan atau masyarakat yang terkait. Arlinghaus \& Krause (2013) menggunakan pendekatan pengetahuan kolektif masyarakat lokal, yang disebut wisdom of the crowd, untuk mengestimasi stok sumber daya ikan di wilayah tertentu. Hipotesis yang mendasari penggunaan pendekatan ini adalah bahwa informasi dan pengetahuan dari individu-individu pengguna sumber daya, apabila dikumpulkan (di data) akan dapat menghasilkan data/informasi yang dibutuhkan untuk mengestimasi ukuran stok sumber daya yang diteliti. Pendekatan tersebut digunakan dalam kondisi dimana data yang dibutuhkan dalam analisis stok konvensional tidak tersedia (statistik hasil tangkapan, catch per unit effort, dan lain-lain). Tingkat akurasi estimasi stok ikan melalui pendekatan ini masih memerlukan pembuktian dari beberapa penelitian empiris serupa.

Lebih jauh lagi Arlinghaus mengingatkan pentingnya pemahaman terhadap berbagai jenis atau tipe pemangku kepentingan terhadap sumber daya yang dikaji. Dalam penelitian yang dilakukan bersama beberapa rekannya (Aminpour, Gray, Jetter, Introne, Singer, \& Arlinghaus, 2020), Arlinghaus menyatakan bahwa menggunakan informasi atau pengetahuan hanya dari satu jenis pemangku kepentingan justru berpotensi mengarah pada adanya akumulasi konsep pemikiran yang keliru (mengenai pengelolaan sumber daya) dan mitos-mitos yang timbul di dalam kalangan masyarakat tersebut. Hal ini dapat terjadi dalam kondisi dimana pemangku kepentingan merupakan individu-individu yang kehidupannya berada dan erikat dalam komunitas atau adat, dimana interaksi sosial (dan pranata sosial di dalamnya) diantara mereka akan menghasilkan kognisi kolektif, yang terwujud dalam pemahaman dan aksi bersama. Pertanyaan yang timbul kemudian adalah apakah kognisi kolektif komunitas pengguna sumber daya tersebut dapat otomatis disebut sebagai arif atau bijaksana hanya karena sudah berlangsung lama. Dalam konteks tersebut, tata kelola sumber daya ikan disarankan untuk tetap mengacu pada pedoman teknis yang dikeluarkan oleh yang berwenang (Arlinghaus, Cooke, Sutton, Danylchuk, Potts, Freire, Alos, Da Silva, Cowx, 2016).

Mengacu pada kondisi tersebut, dapat dipahami bahwa tidak semua praktik masyarakat tradisional/hukum adat otomatis dapat disebut sebagai pengelolaan yang arif. Penyebutan suatu praktik pengelolaan masyarakat sebagai kearifan lokal tidak dapat didasari hanya karena praktik tersebut sudah dilakukan sejak lama atau turuntemurun, namun harus berlandaskan pada suatu kriteria tertentu yang mendukung pengelolaan perikanan berkelanjutan. Apabila suatu praktik pengelolaan dianggap arif tetapi sebenarnya tidak dilakukan berdasarkan asas-asas pengelolaan berkelanjutan yang berlaku universal maka sumber daya tersebut akan terdegradasi atau bahkan hancur. Oleh sebab itu, KKP dan kalangan akademisi perlu menetapkan cara mengukur praktik pengelolaan yang dilakukan masyarakat tradisional/ hukum adat agar benar-benar dapat dikategorikan sebagai satu kearifan dalam pengelolaan sumber daya perikanan.

Definisi kearifan yang dikemukakan oleh Baltes \& Staudinger (2000) ini telah menjadi acuan dari berbagai penelitian dan kajian seperti halnya mengenai panduan psikologi \& pengembangan manusia, panduan penanganan perilaku \& kognitif (Damon \& Lemer, 2006; Ferrari \& Potworowski, 2008), termasuk juga penelitian mengenai pemahaman kearifan melalui perspektif lintas budaya (Bond \& Dryden, 2002). Dengan demikian, dapat disimpulkan bahwa definisi tersebut telah menginspirasi berbagai tulisan dan kajian penting dalam ilmu psikologi. Oleh sebab itu, keabsahannya dapat dipakai sebagai dasar penentuan tolok ukur kearifan dalam penelitian ini.

Penelitian ini ditujukan untuk merancang tolok ukur kearifan dalam pengelolaan sumber daya perikanan dengan landasan kerangka pemikiran 
Baltes \& Staudinger (2000) mengenai definisi kearifan yang dikombinasikan dengan berbagai parameter atau indikator pengelolaan perikanan berkelanjutan yang dikembangkan oleh Food and Agricultural Organization (FAO) pada tahun 1995 melalui pedoman Code of Conduct for Responsible Fisheries (CCRF) dan karya tulis Garcia (1996). Dipahami bahwa indikator pengelolaan perikanan berkelanjutan telah banyak mengalami perkembangan sesuai dengan berkembangnya konsep berkelanjutan itu sendiri, dimana pilihan perangkat indikator-indikator ditentukan oleh fokus penelitian masing-masing ahli ataupun disesuaikan dengan ketersediaan data, sehingga tidak serta merta dapat digunakan pada lokasi atau kondisi berbeda ataupun memberikan kajian menyeluruh terhadap kondisi sumber daya yang diteliti (Dudley, Baldock, Nasi \& Stolton, 2005). Oleh sebab itu, penelitian ini menggunakan pedoman teknis dari CCRF dan Garcia (1996) yang telah direkomendasikan oleh FAO. Rancangan tolok ukur tersebut selanjutnya diuji cobakan pada desa/kelompok masyarakat yang selama ini telah disebut sebagai desa/masyarakat yang memiliki kearifan lokal.

Hasil penelitian ini dapat dijadikan rujukan untuk menilai tingkat kearifan suatu praktik pengelolaan perikanan di masyarakat. Hasil penilaian tersebut selanjutnya dapat digunakan pemerintah pusat atau provinsi untuk menentukan langkah selanjutnya dalam pengalokasian dana, fasilitasi maupun pemberian hak-hak pengelolaan sumber daya tertentu. Desa Adat Kedonganan dipilih sebagai lokasi uji coba karena desa tersebut telah ditetapkan Kementerian Kelautan dan Perikanan (KKP) sebagai desa yang memiliki kearifan lokal dalam pengelolaan sumber daya perikanan dalam program "Penguatan Peran Masyarakat Hukum Adat dalam Pengelolaan Sumber daya Laut di Wilayah Pesisir dan Pulau Pulau Kecil" pada tahun 2017.

Responden uji coba tolok ukur tingkat kearifan ini adalah masyarakat Desa Adat Kedonganan yang terdiri dari dua kelompok yaitu prajuru adat dan kelompok nelayan. Responden prajuru adat adalah lima orang prajuru adat, sedangkan responden nelayan berjumlah dua puluh enam orang atau sepuluh persen dari 260 nelayan. Penentuan responden dilakukan melalui konsultasi dengan ketua kelompok nelayan setempat (enam kelompok). Prajuru adat adalah pengurus Desa Adat yang terdiri dari Bendesa (kepala), Baga Pawongan, Baga Palemahan, Baga Parahyangan dan Ketua Pasar Adat. Adapun diskusi dan wawancara dilakukan pada bulan Juni sampai Agustus 2019.

Penelitian ini dapat dikategorikan sebagai penelitian yang menggunakan pendekatan kualitatif (Cresswel, 2014; Neuman, 2003). Penelitian ini dapat pula dikategorikan sebagai participatory action research karena menggunakan interaksi dan diskusi langsung dengan para pemangku kepentingan. Wawancara dilakukan untuk mengetahui dasar pemikiran, proses perencanaan serta aksi praktik lokal pengelolaan sumber daya perikanan masyarakat Desa Adat Kedonganan sesuai dengan kelima kriteria di aspek factual knowledge maupun aspek prosedural knowledge. Hasil wawancara diolah dan dikuantifikasi menggunakan skala likert (Likert, 1932). Sistem

Tabel 1. Perhitungan ketercapaian Tolok Ukur.

Table 1. Valuation of Benchmark Achievement.

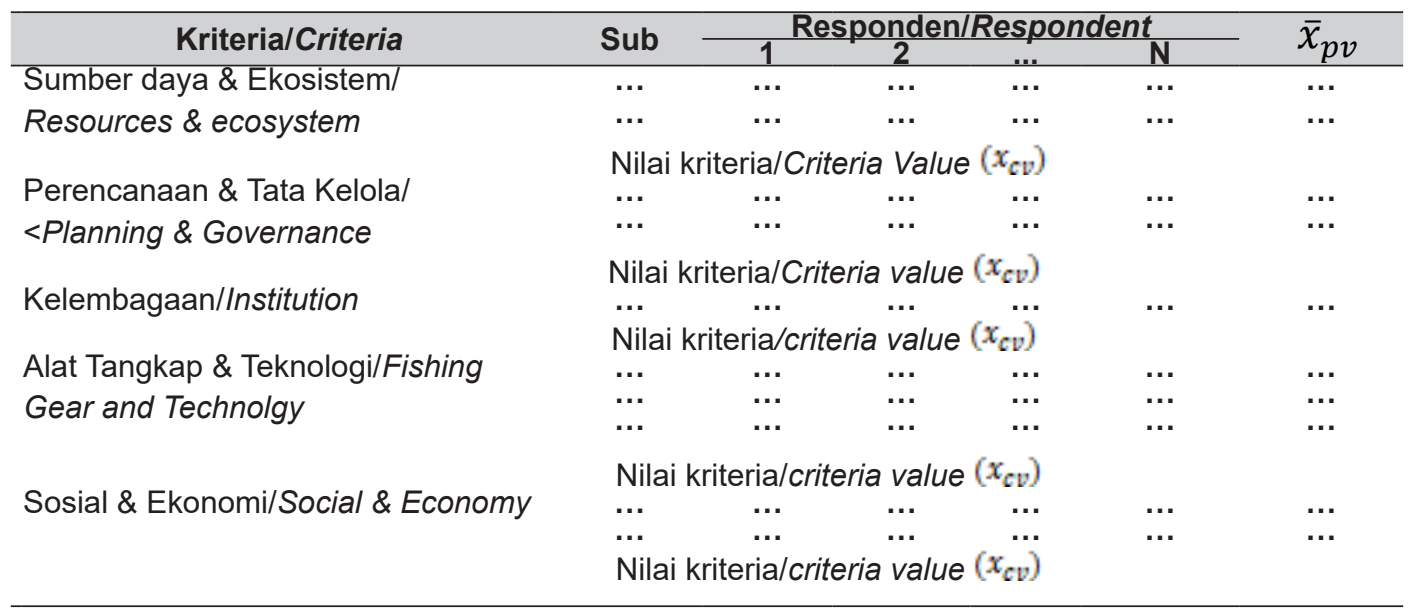

Sumber: Modifikasi skala Likert (1932) dengan penggunaan Microsoft Excel./ Source: modified Likert scale (1932) with the use of Microsoft Excel. 
skoring yang digunakan berbasis 4 kategori: paham (1), tahu $(0,75)$, ragu-ragu $(0,5)$, tidak paham (0). Perhitungan nilai kearifan dibantu perangkat lunak Microsoft Excel 2016 untuk memperoleh nilai akhir tingkat kearifan masyarakat. berikut:

Rumusan perhitungan dirumuskan sebagai

Berdasarkan nilai $x_{c v}$ atau nilai kriteria pada tolok ukur yang diperoleh dari pengolahan nilai

$$
\bar{x}_{p v}=\frac{x R_{1}+x R_{2}+\ldots+x R_{n}}{n}
$$

Keterangan:

$$
\begin{aligned}
& \bar{x}_{p v} \quad \text { : Rata-rata nilai responden untuk } \\
& x_{c v}=\frac{\sum x_{p v}}{n_{s c}} \\
& \mathrm{X}_{\mathrm{CV}} \quad \text { : Nilai Kriteria } \\
& \mathrm{X}_{\mathrm{pv}} \quad \text { : Nilai Parameter } \\
& n_{S C} \quad \text { : Jumlah Parameter Dalam Satu Kriteria }
\end{aligned}
$$

parameter baik aspek factual knowledge serta aspek procedural knowledge penentuan ketercapaian dikelompokkan ke dalam empat kategori seperti berikut pada Tabel 2. Kategori tingkat kearifan tidak teridentifikasi menunjukkan bahwa responden hampirtidakmemiliki pemahaman ataupun tindakan yang sesuai dengan kriteria keberlanjutan sumber daya. Tingkat kearifan lemah berarti responden memiliki dasar pemahaman ataupun melakukan tindakan tertentu, namun masih terlalu kecil untuk menjamin keberlanjutan sumber daya. Tingkat kearifan moderat berarti responden memiliki pemahaman dan aksi yang cukup baik untuk menjaga keberlanjutan sumber daya. Adapun tingkat kearifan kuat berarti responden telah memiliki pemahaman yang sangat baik dan melakukan berbagai tindakan yang dapat menjamin keberlanjutan sumber daya.

\section{A. Tolok Ukur Kearifan Dalam Pengelolaan Sumber Daya Perikanan}

Kearifan manusia menurut Baltes dan Staudinger (2000) dapat diukur dari dua hal yaitu aspek factual knowledge yaitu pengetahuan serta pemahaman terhadap subyek yang dikelola, dan aspek procedural knowledge yaitu kesesuaian perilaku dan tindakan yang dipraktikan dalam mengelola subjek tersebut. Secara keseluruhan nilai kearifan seseorang merupakan tindakan aksi yang didasari oleh pemikiran, perencanaan dan pengorganisasian dalam menjalankan sesuatu. Penelitian ini menggunakan definisi tersebut untuk membagi penilaian kearifan pada dua aspek yaitu pemahaman dan persepsi (factual knowledge) dan prosedur dan tindakan (procedural knowledge).

Pengetahuan faktual (factual knowledge) menurut Baltes \& Staudinger (2000) didefinisikan sebagai pengetahuan mendasar suatu individu ataupun kelompok masyarakat menyangkut halhal esensial seperti hubungan interpersonal atau antarkelompok, perkembangan, norma sosial, serta pengetahuan untuk saling berkoordinasi untuk mencapai hal-hal yang baik. Dalam hal pengelolaan sumber daya perikanan berdasarkan definisi tersebut, factual knownledge dapat dimaknai sebagai pengetahuan individu atau kelompok masyarakat berkaitan dengan pengetahuan dasar mengenai norma-norma dan tata koordinasi dalam pemanfaatan atau pengelolaan sumber daya perikanan yang baik dan berkelanjutan. Dengan kata lain, dapat disimpulkan bahwa pengetahuan faktual (factual knowledge) merupakan dasar pemahaman dalam suatu kearifan pengelolaan perikanan.

Tabel 2. Nilai Capaian Kriteria Kearifan Pada Pengelolaan Sumber Daya. Table 2. Achieved Wisdom Value Criteria on Resource Management.

\begin{tabular}{cl}
$\begin{array}{c}\text { Nilai } \mathrm{x}_{\mathrm{cv}} \\
\text { Value } \mathrm{x}_{\mathrm{cv}} \text { ( }\end{array}$ (Nitaiteria Value of Benchmark) & Kategori/Category \\
\hline $\mathrm{x}_{\mathrm{cv}}<0.25$ & Tingkat kearifan tidak teridentifikasi/Wisdom value unidentified \\
$0.25 \leq \mathrm{x}_{\mathrm{cv}}<0.5$ & Tingkat kearifan lemah/Wisdom value is weak \\
$0.5 \leq \mathrm{x}_{\mathrm{cv}}<0.75$ & Tingkat kearifan moderat/Wisdom value is moderate \\
$0.75 \leq \mathrm{x}_{\mathrm{cv}} \leq 1$ & Tingkat kearifan kuat/Wisdom value is strong \\
\hline
\end{tabular}

Sumber: Hasil modifikasi dari Likert (1932) untuk kesesuaian penelitian/

Source: Modified results from Likert (1932) for the suitability of the study 
Adapun procedural knowledge atau pengetahuan prosedural didefinisikan sebagai pengetahuan pragmatis, atau rasional strategis yang berkaitan dengan perilaku dalam penataan dan pertimbangan tujuan termasuk cara penanganan konflik dan pembuatan keputusan alternatif. Definisi procedural knowledge dalam kaitannya dengan pengelolaan sumber daya perikanan yang berkelajutan dapat dimaknai sebagai pengetahuan individu atau kolektif berupa tindakan strategis dalam menetapkan tujuan, menata, mengelola serta memanajemen konflik yang mungkin terjadi pada suatu pengelolaan sumber daya perikanan yang berkelanjutan. Procedural Knowledge juga dapat disimpulkan sebagai aspek tindakan atau aksi dalam kearifan pengelolaan perikanan.
Garcia (1996) mengusung berbagai indikator dan kriteria yang dapat dipililih atau digunakan untuk mengukur tingkat keberlanjutan dari pengelolaan suatu sumber daya perikanan sesuai dengan kebutuhan dan konteks kemasyarakatan. Food and Agricultural Organization (FAO) sebelumnya mengeluarkan panduan bagaimana mengelola sumber daya perikanan berkelanjutan melalui code of Conduct for Responsible Fisheries (1995). Ekstraksi dari opsi kriteria yang ditawarkan oleh Garcia (1996) adalah: a) sumber daya dan lingkungan; b) perencanaan dan tata kelola; c) kelembagaan; d) alat tangkap dan teknologi; e) sosial ekonomi. Tiap kriteria dipertajam dengan beberapa parameter pengelolaan perikanan berkelanjutan.

Tabel 3. Tolok Ukur Kearifan Pengelolaan Perikanan Berkelanjutan Aspek Factual Knowledge. Table 3. Fisheries Sustainable Management Wisdom Benchmark on Factual Knowledge.

\begin{tabular}{|c|c|c|c|}
\hline $\begin{array}{c}\text { Kriteria/ } \\
\text { Criteria }\end{array}$ & Sub & Indikator/indicator & Parameter/parameter \\
\hline \multirow{4}{*}{$\begin{array}{l}\text { Sumber daya } \\
\text { \& Ekosistem/ } \\
\text { Ecosystem and } \\
\text { resource }\end{array}$} & a & $\begin{array}{l}\text { Ketersediaan sumber daya } \\
\text { perikanan/Resource availability }\end{array}$ & $\begin{array}{l}\text { Sumber daya perikanan tidak selalu tersedia dan } \\
\text { ketersediaannya dipengaruhi oleh kegiatan penangkapan/ } \\
\text { Resource not always available and it affected by fishing. }\end{array}$ \\
\hline & b & $\begin{array}{l}\text { Dampak antropogenik/ } \\
\text { Anthropogenic impact }\end{array}$ & $\begin{array}{l}\text { kegiatan pemanfaatan sumber daya maupun pencemaran } \\
\text { akan berpengaruh pada sumber daya/Fishing and } \\
\text { polluting have impact on resource. }\end{array}$ \\
\hline & c & $\begin{array}{l}\text { Kepedulian pada sumber daya/ } \\
\text { Resource stewardship }\end{array}$ & $\begin{array}{l}\text { kepedulian dan penjagaan kawasan pesisir berdampak } \\
\text { positif pada keberlanjutan sumber daya/Stewardship } \\
\text { on coastal area has positive impact for resource } \\
\text { sustainability. }\end{array}$ \\
\hline & $d$ & $\begin{array}{l}\text { Status pemanfaatan sumber } \\
\text { daya/Resource status }\end{array}$ & $\begin{array}{l}\text { status atau kecenderungan kondisi pemanfaatan sumber } \\
\text { daya/Status or trend on fishing condition }\end{array}$ \\
\hline \multirow{2}{*}{$\begin{array}{l}\text { Perencanaan } \\
\text { \& tata kelola/ } \\
\text { Planning \& } \\
\text { governance }\end{array}$} & a & $\begin{array}{l}\text { Aturan \& sanksi/Rules and } \\
\text { sanctions }\end{array}$ & $\begin{array}{l}\text { aturan dan sanksi merupakan hal yang penting dalam } \\
\text { praktik pengelolaan sumber daya perikanan/Rules and } \\
\text { sanction is important in resource management }\end{array}$ \\
\hline & $\mathrm{b}$ & $\begin{array}{l}\text { Saran dan Masukan pada } \\
\text { perencanaan \& tata kelola/ } \\
\text { Recommendation and input for } \\
\text { planning \& governance }\end{array}$ & $\begin{array}{l}\text { melaksanakan seluruh peraturan/ sistem tata kelola } \\
\text { perikanan /Implementation of all system and rules }\end{array}$ \\
\hline $\begin{array}{l}\text { Kelembagaan/ } \\
\text { Institution }\end{array}$ & a & $\begin{array}{l}\text { Partisipasi aktif/Active } \\
\text { participation }\end{array}$ & $\begin{array}{l}\text { praktik pengelolaan sumber daya perikanan harus } \\
\text { melibatkan seluruh anggota masyarakat termasuk } \\
\text { pemerintah setempat/Resource management must } \\
\text { include all staeholders including local government. }\end{array}$ \\
\hline \multirow{2}{*}{$\begin{array}{l}\text { Alat tangkap } \\
\text { \& teknologi/ } \\
\text { Fishing gear } \\
\text { and technology }\end{array}$} & a & $\begin{array}{l}\text { Alat tangkap ramah lingkungan/ } \\
\text { Environment friendly gear }\end{array}$ & $\begin{array}{l}\text { kewajiban penggunaan alat tangkap ramah lingkungan } \\
\text { dalam pemanfaatan sumber daya ikan/Compliance in } \\
\text { using enviroment friendly fishing gears }\end{array}$ \\
\hline & $\mathrm{b}$ & $\begin{array}{l}\text { Pencegahan by catch/Avoid by- } \\
\text { catch }\end{array}$ & $\begin{array}{l}\text { tindakan penanganan untuk mencegah discard atau by } \\
\text { catch/Discard or by-catch prevention }\end{array}$ \\
\hline \multirow{3}{*}{$\begin{array}{l}\text { Sosial \& } \\
\text { ekonomi/ } \\
\text { Social \& } \\
\text { economy }\end{array}$} & a & $\begin{array}{l}\text { Kebermanfaatan sumber daya/ } \\
\text { Resource benefit }\end{array}$ & $\begin{array}{l}\text { memperoleh manfaat atas sumber daya Perikanan/ } \\
\text { Benefit from resources }\end{array}$ \\
\hline & b & $\begin{array}{l}\text { Manfaat proses konservasi/ } \\
\text { Conservation benefit }\end{array}$ & $\begin{array}{l}\text { proses konservasi atau penjagaan sumber daya ikan } \\
\text { akan menghasilkan keuntungan ekonomis kelak/Future } \\
\text { benefit from resource conservation or protection }\end{array}$ \\
\hline & c & $\begin{array}{l}\text { Pencegahan konflik/Conflict } \\
\text { prevention }\end{array}$ & upaya meminimalkan konflik/Conflict resolution effort \\
\hline
\end{tabular}

Sumber: Sintesis dari Baltes dan Straudinger (2000) dengan Garcia (1996) dan FAO (1995).I

Source: synthesis from Baltes and Straudinger (2000) with Garcia (1996) and FAO (1995). 
Sintesis antara definisi kearifan dengan kriteria pengelolaan berkelanjutan menghasilkan satu tolok ukur tingkat kearifan pengelolaan sumber daya perikanan yang terdiri dari dua aspek, yaitu aspek pemikiran/persepsi dan aspek perilaku/tindakan. Kedua aspek tersebut masingmasing diukur dengan lima kriteria pengelolaan berkelanjutan yang memiliki beberapa parameter terpilih (Tabel 3 dan Tabel 4).

\section{B. Uji Coba Tolok Ukur Kearifan Lokal Pengelolaan Perikanan Berkelanjutan pada Masyarakat Adat Desa Kedonganan}

Tolok ukur kearifan pada pengelolaan perikanan yang berkelanjutan mengukur tingkat kearifan pada aspek factual knowledge dan aspek procedural knowledge. Aspek factual knowledge mewakili dasar pemikiran kelompok masyarakat

Tabel 4. Tolok Ukur Kearifan Pengelolaan Perikanan Berkelanjutan Aspek Procedural Knowledge. Table 4. Fisheries Sustainable Management Wisdom Benchmark on Procedural Knowledge.

\begin{tabular}{|c|c|c|c|}
\hline Kriteria/Criteria & Sub & Indikator/Indicator & Parameter/Parameter \\
\hline \multirow[t]{4}{*}{$\begin{array}{l}\text { Sumber daya \& } \\
\text { Ekosistem/Ecosystem } \\
\text { and resource }\end{array}$} & a & $\begin{array}{l}\text { Area konservasi berbasis } \\
\text { ilmiah/scientific based } \\
\text { conservation area }\end{array}$ & $\begin{array}{l}\text { Pembentukan kawasan atau waktu larang tangkap pada waktu, } \\
\text { area, habitat atau spesies tertentu di daerah pemanfaatan } \\
\text { disertai justifikasi ilmiah yang memadai/Science was used to } \\
\text { determine conservation area, no take zone, prohibited species. }\end{array}$ \\
\hline & $\mathrm{b}$ & $\begin{array}{l}\text { Pemantauan upaya/Monitoring } \\
\text { system }\end{array}$ & $\begin{array}{l}\text { Pembentukan sistem pemantauan upaya penangkapan/Fishing } \\
\text { monitoring effort }\end{array}$ \\
\hline & C & $\begin{array}{l}\text { Pencegahan antropogenik/ } \\
\text { Anthropogenic control }\end{array}$ & $\begin{array}{l}\text { Pelarangan pembuangan sampah, limbah atau bahan } \\
\text { pencemar di sekitar/Pollution control }\end{array}$ \\
\hline & C & $\begin{array}{l}\text { Perizinan khusus wilayah kritis/ } \\
\text { Special permit on critical area }\end{array}$ & $\begin{array}{l}\text { Pelarangan atau izin khusus pada pemanfaatan tanaman } \\
\text { bakau, lamun atau terumbu/Prohibition or permit for mangrove/ } \\
\text { coral reef use }\end{array}$ \\
\hline \multirow[t]{5}{*}{$\begin{array}{l}\text { Perencanaan \& tata } \\
\text { kelola/Planning and } \\
\text { governance }\end{array}$} & a & $\begin{array}{l}\text { Penentuan ruang lingkup } \\
\text { pengelolaan/Defined } \\
\text { management scope }\end{array}$ & $\begin{array}{l}\text { Pendefinisian rencana aksi serta batasan dan manajemen } \\
\text { pengelolaan sumber daya ikan/Management scope and action } \\
\text { plan defined }\end{array}$ \\
\hline & $b$ & $\begin{array}{l}\text { Sistem pengawasan/ } \\
\text { Surveillance system }\end{array}$ & $\begin{array}{l}\text { Pembentukan mekanisme untuk pengawasan, pengendalian } \\
\text { dan evaluasi/Development of control and surveillance and } \\
\text { evaluation }\end{array}$ \\
\hline & C & $\begin{array}{l}\text { Kesetaraan hak dalam } \\
\text { pemanfaatan/Inclusive access } \\
\text { rights }\end{array}$ & $\begin{array}{l}\text { Pertimbangan hak dan kesetaraan akses dalam upaya } \\
\text { penangkapan/Inclusive rights for fishing }\end{array}$ \\
\hline & d & Riset/Research & $\begin{array}{l}\text { penelitian mengenai sumber daya, upaya serta kapasitas } \\
\text { penangkapan perikanan/Research on resources, fishing effort } \\
\text { and capacity }\end{array}$ \\
\hline & e & $\begin{array}{l}\text { Pendataan dan } \\
\text { pengorganisasian hasil } \\
\text { tangkapan/Data collection and } \\
\text { statistics }\end{array}$ & $\begin{array}{l}\text { data statistik tata kelola serta organisir hasil tangkapan/Catch } \\
\text { statistics and governance }\end{array}$ \\
\hline \multirow[t]{3}{*}{$\begin{array}{l}\text { Kelembagaan/ } \\
\text { Institution }\end{array}$} & a & $\begin{array}{l}\text { Otoritas manajemen/ } \\
\text { Management authority }\end{array}$ & $\begin{array}{l}\text { penerapan dan otoritas manajemen yang terstruktur dengan } \\
\text { baik/Well structured management authority and implementation }\end{array}$ \\
\hline & $\mathrm{b}$ & $\begin{array}{l}\text { Transparansi pengelolaan/ } \\
\text { Mangement transparancy }\end{array}$ & $\begin{array}{l}\text { Transparansi pengelolaan dan pengambilan keputusan/ } \\
\text { Transparancy on management and decision making }\end{array}$ \\
\hline & C & $\begin{array}{l}\text { Partisipasi aktif/Active } \\
\text { participation }\end{array}$ & $\begin{array}{l}\text { Penetapan tujuan pengelolaan berdasakan proses partisipatif/ } \\
\text { Management objective based on participatory process }\end{array}$ \\
\hline \multirow{4}{*}{$\begin{array}{l}\text { Alat tangkap \& } \\
\text { teknologi/Fishing gear } \\
\text { and technology }\end{array}$} & a & $\begin{array}{l}\text { Penerapan alat tangkap legal/ } \\
\text { Use of legal fishing gear }\end{array}$ & $\begin{array}{l}\text { Penerapan aturan pemerintah tentang alat tangkap maupun } \\
\text { aturan penangkapan/Implementation of government regulations }\end{array}$ \\
\hline & $b$ & $\begin{array}{l}\text { Pengendalian upaya tangkap/ } \\
\text { Fishing monitoring }\end{array}$ & $\begin{array}{l}\text { Penetapan batas pada jumlah alat tangkap yang beroperasi/ } \\
\text { Limiting number of fishing gears }\end{array}$ \\
\hline & C & $\begin{array}{l}\text { Pelarangan bahan atau alat } \\
\text { ilegal/Prohibit use of illegal gear } \\
\text { or substance }\end{array}$ & $\begin{array}{l}\text { Pelarangan terhadap bahan kimia berbahaya dan bom serta } \\
\text { racun pada kegiatan penangkapan ikan/Prohibit use of toxic } \\
\text { chemical, poison and bomb for fishing }\end{array}$ \\
\hline & $d$ & $\begin{array}{l}\text { Pengurangan by catch/ } \\
\text { Minimilize by catch and discard }\end{array}$ & $\begin{array}{l}\text { Meminimalkan by-catch dan hasil tangkapan yang dibuang/ } \\
\text { Minimized by catch and discard }\end{array}$ \\
\hline \multirow[t]{2}{*}{$\begin{array}{l}\text { Sosial \& ekonomi/ } \\
\text { Social \& economy }\end{array}$} & a & $\begin{array}{l}\text { Penanganan konflik/Conflict } \\
\text { resolution }\end{array}$ & Konflik komunitas pada praktik pengelolaan/Conflict resolution \\
\hline & $b$ & $\begin{array}{l}\text { Perkembangan ekonomi/ } \\
\text { Economic development }\end{array}$ & $\begin{array}{l}\text { kegiatan ekonomi sektor perdagangan maupun sektor } \\
\text { pariwisata/Economic activities on trade and tourism }\end{array}$ \\
\hline
\end{tabular}

Sumber: Sintesis dari Baltes dan Straudinger (2000) dengan Garcia (1996) dan FAO (1995).I

Source: synthesis from Baltes and Straudinger (2000) with Garcia (1996) and FAO (1995). 
pada proses perencanaan pengelolaan sumber daya perikanan yang ada. Sedangkan aspek procedural knowledge merepresentasikan praktik ataupun aksi yang dilakukan oleh kelompok masyarakat dalam pengelolaan sumber daya perikanan.

\section{Persepsi dan Pemahaman Terhadap Pengelolaan Sumber Daya Perikanan}

Adat dan kepercayaan yang dianut oleh masyarakat adat Kedonganan merupakan hal yang menjadi dasar pemikiran perencanaan tata kelola yang berlaku saat ini. Hal ini karena prajuru desa selaku pemegang adat dipercaya seluruh masyarakat di desa, sehingga persepsi serta pemahaman dalam pengelolaan yang ada di Desa Adat Kedonganan sangat terkait dengan kepercayan yang dianut oleh sebagian besar masyarakat Desa Kedonganan. Pengukuran terhadap beberapa kriteria perikanan berkelanjutan menunjukkan tingkat persepsi dan pemahaman kedua kelompok masyarakat tersebut.

\section{Persepsi dan Pemahaman Pada Kriteria Sumber Daya \& Ekosistem}

Hasil wawancara dan pengamatan yang dilakukan terhadap dua kelompok masyarakat Desa Adat Kedonganan menunjukkan bahwa keduanya belum memahami secara baik bahwa sumber daya perikanan tidak akan selalu tersedia dan ketersediaannya dipengaruhi oleh kegiatan penangkapan atau pemanfaatan. Mereka beranggapan bahwa ikan tidak akan habis dan sumber daya perikanan di wilayah tersebut dalam kondisi yang cenderung tetap, walaupun mereka mengetahui pentingya kepedulian untuk menjaga laut dan pesisir Adapun pemahaman bahwa pencemaran akan mempengaruhi keberadaan sumber daya hanya dipahami oleh sebagian nelayan maupun prajuru adat. Pengukuran tingkat capaian keberlanjutan untuk kriteria ekosistem dan sumber daya pada aspek persepsi dan pemahaman (factual knowledge), tertera pada Tabel 5.

Nilai capaian persepsi dan pemahaman prajuru adat lebih tinggi dari nelayan, walaupun pada kriteria ketersediaan sumber daya keduanya menunjukkan ketidakpahaman. Rendahnya tingkat pemahaman ini akan menimbulkan fenomena tragedy of the common, dimana setiap nelayan akan memaksimalkan eksploitasi terhadap sumber daya yang ada sampai terjadi tangkap lebih (over fishing). Keadaan yang berlangsung terus menerus akan berakibat fatal berupa kehancuran sumber daya yang ada (Hardin, 1968). Secara keseluruhan pada kriteria ekosistem dan sumber daya berdasarkan selang yang telah ditetapkan

Tabel 5. Nilai Capaian Kriteria Sumber Daya dan Ekosistem Pada Aspek Factual Knowledge. Table 5. Value for Ecosystem and Resource on Factual Knowledge Aspect.

\begin{tabular}{|c|c|c|c|c|c|}
\hline $\begin{array}{l}\text { Kriteria/ } \\
\text { Criteria }\end{array}$ & Sub & $\begin{array}{l}\text { Indikatorl } \\
\text { Indicators }\end{array}$ & $\begin{array}{l}\text { Parameter/ } \\
\text { Parameter }\end{array}$ & $\begin{array}{l}\text { Nilai } \\
\text { Nelayan/ } \\
\text { Fishers } \\
\text { Value }\end{array}$ & $\begin{array}{l}\text { Nilai } \\
\text { Prajuru Desal } \\
\text { Value Adat } \\
\text { Leaders }\end{array}$ \\
\hline \multirow[t]{4}{*}{$\begin{array}{l}\text { Sumber daya } \\
\text { \& Ekosistem/ } \\
\text { ecosystem and } \\
\text { resource }\end{array}$} & $a$ & $\begin{array}{l}\text { Ketersediaan } \\
\text { sumber daya } \\
\text { perikanan/ } \\
\text { resource } \\
\text { avaliability }\end{array}$ & $\begin{array}{l}\text { sumber daya perikanan tidak selalu } \\
\text { tersedia dan ketersediaannya } \\
\text { dipengaruhi oleh kegiatan penangkapan/ } \\
\text { resource not always available and it is } \\
\text { affected by fishing. }\end{array}$ & 0.00 & 0.00 \\
\hline & $b$ & $\begin{array}{l}\text { Dampak } \\
\text { Antropogenik/ } \\
\text { anthropogenic } \\
\text { impact }\end{array}$ & $\begin{array}{l}\text { kegiatan pemanfaatan sumber daya } \\
\text { maupun pencemaran akan berpengaruh } \\
\text { pada sumber daya/fishing and polluting } \\
\text { have impact on resource. }\end{array}$ & 0.21 & 0.40 \\
\hline & c & $\begin{array}{l}\text { Kepedulian } \\
\text { pada sumber } \\
\text { daya/resource } \\
\text { stewardship }\end{array}$ & $\begin{array}{l}\text { kepedulian dan penjagaan kawasan } \\
\text { pesisir berdampak positif pada } \\
\text { keberlanjutan sumber daya/stewardship } \\
\text { on coastal area has positive impact for } \\
\text { resource sustainability. }\end{array}$ & 0.67 & 0.80 \\
\hline & $d$ & $\begin{array}{l}\text { Status } \\
\text { pemanfaatan } \\
\text { sumber daya/ } \\
\text { fishing condition }\end{array}$ & $\begin{array}{l}\text { status atau kecenderungan kondisi } \\
\text { pemanfaatan sumber daya/status or } \\
\text { trend on fishing condition }\end{array}$ & 0.50 & 0.60 \\
\hline \multicolumn{4}{|c|}{ Nilai kriteria } & 0.35 & 0.45 \\
\hline
\end{tabular}

Sumber: Wawancara prajuru adat dan nelayan/Source: interview on adat leaders and fishers. 
berada pada selang kearifan lemah, baik pada kelompok nelayan maupun pada kelompok prajuru desa.

\section{Persepsi dan Pemahaman pada Perencanaan dan Tata Kelola}

Masyarakat nelayan serta prajuru adat dinilai memahami indikator aturan dan sanksi. Hal ini terlihat dari nilai pemahamannya pada parameter indikator tersebut sebesar 0,63 dan 0,65 (Tabel 6) yang berarti bahwa keduanya telah menyadari bahwa aturan dan sanksi merupakah hal yang perlu/penting dalam praktik pengelolaan sumber daya. Menurut Sandita (2012) perangkat aturan untuk mendukung siklus biologis ikan yang baik pada sumber daya yang ada merupakan hal yang diperlukan untuk memastikan keberlanjutan suatu sumber daya.

Sebagian besar nelayan atau prajuru desa telah mengetahui bahwa peraturan dalam tata kelola merupakan hal yang penting. Namun demikian, para nelayan belum sepenuhnya memahami proses dalam memberikan masukan kepada rencana serta tata kelola yang ada. Nelayan cenderung belum memiliki pemahaman yang utuh dalam menyampaikan pendapat serta sarannya. Mereka hanya membicarakan di antara mereka tapi tidak menyampaikan langsung pada prajuru adat, sehingga tidak ada umpan balik terhadap tata kelola perikanan di Desa Adat Kedonganan.
Oleh sebab itu, kelompok nelayan tergolong pada kearifan yang lemah, sedangkan kelompok prajuru desa tergolong pada kearifan yang moderat (Tabel 6).

\section{Persepsi dan Pemahaman Pada Kelembagaan}

Terdapat dua kelembagaan perikanan yang terbentuk di Desa Adat Kedonganan yaitu kelembagaan prajuru desa adat yang mengelola pasar adat dan sektor perikanan secara umum, serta kelembagaan masyarakat nelayan yang berbentuk kelompok-kelompok nelayan. Nelayan Kedonganan beranggapan bahwa tidak perlu melibatkan banyak pihak dalam mengelola sumber daya perikanan yang ada (nilai 0,25). Padahal, seharusnya dibutuhkan keterlibatan banyak pihak dan kalangan seperti pemerintah adat atau pemerintahan daerah, pelaku ekonomi, periset serta pihak lainnya untuk memastikan pengelolaan sumber daya perikanan yang ada menjadi berkelanjutan. Para prajuru desa telah memahami dengan baik bahwa partisipasi serta kolaborasi berbagai pihak memang diperlukan walaupun sebagian di antara mereka beranggapan bahwa partisipasi tersebut dapat diwakilkan oleh beberapa orang tertentu (nilai 0,75). Oleh karena itu, nilai kriteria yang didapat untuk kelompok nelayan termasuk ke dalam golongan kearifan lemah. Nilai pada prajuru desa menunjukkan tingkat kearifan yang kuat. Penilaian kriteria kelembagaan pada aspek factual knowledge disajikan pada Tabel 7.

Tabel 6. Nilai Capaian Kriteria Perencanaan dan Tata Kelola Pada Aspek Factual Knowledge. Table 6. Value for Planning and Governance Criteria on Factual Knowledge.

\begin{tabular}{|c|c|c|c|c|c|}
\hline $\begin{array}{l}\text { Kriteria/ } \\
\text { Criteria }\end{array}$ & Sub & $\begin{array}{l}\text { Indikatorl } \\
\text { Indicators }\end{array}$ & $\begin{array}{l}\text { Parameter/ } \\
\text { Parameter }\end{array}$ & $\begin{array}{c}\text { Nilai Anggota } \\
\text { Masyarakat/ Value } \\
\text { of Community } \\
\text { Members }\end{array}$ & $\begin{array}{c}\text { Nilai } \\
\text { Prajuru Desal } \\
\text { Value Adat } \\
\text { Leaders }\end{array}$ \\
\hline \multirow[t]{2}{*}{$\begin{array}{l}\text { Perencanaan } \\
\text { \& tata kelola/ } \\
\text { Planing and } \\
\text { governance }\end{array}$} & $a$ & $\begin{array}{l}\text { Aturan \& sanksi/Rules } \\
\text { and sanctions }\end{array}$ & $\begin{array}{l}\text { Aturan dan sanksi } \\
\text { merupakan hal yang } \\
\text { penting dalam praktik } \\
\text { pengelolaan sumber } \\
\text { daya perikanan/ } \\
\text { Rules and sanction is } \\
\text { important in resource } \\
\text { management }\end{array}$ & 0.63 & 0.65 \\
\hline & $b$ & $\begin{array}{l}\text { Saran dan Masukan } \\
\text { pada perencanaan \& tata } \\
\text { kelola/Recommendation } \\
\text { and input for planning \& } \\
\text { governance }\end{array}$ & $\begin{array}{l}\text { Melaksanakan seluruh } \\
\text { peraturan/ sistem tata } \\
\text { kelola perikanan / } \\
\text { Implementation of all } \\
\text { system and rules }\end{array}$ & 0.21 & 0.70 \\
\hline
\end{tabular}

$$
\text { Nilai kriteria/criteria value }
$$$$
0.42
$$$$
0.68
$$

Sumber:Wawancara prajuru adat dan nelayan/Source: interview on adat leaders and fishers. 
Tabel 7. Nilai Capaian Kriteria Kelembagaan pada Aspek Factual Knowledge.

Table 7. Value for Institution Criteria on Factual Knowledge.

\begin{tabular}{|c|c|c|c|c|c|}
\hline Kriteria/Criteria & Sub & $\begin{array}{l}\text { Indikator/ } \\
\text { Indicators }\end{array}$ & $\begin{array}{l}\text { Parameter/ } \\
\text { Parameter }\end{array}$ & $\begin{array}{l}\text { Nilai Nelayan/ } \\
\text { Value Fishers }\end{array}$ & $\begin{array}{c}\text { Nilai } \\
\text { Prajuru Desa/ } \\
\text { Value Adat } \\
\text { Leaders }\end{array}$ \\
\hline \multirow[t]{2}{*}{$\begin{array}{l}\text { Kelembagaan/ } \\
\text { Institution }\end{array}$} & $a$ & $\begin{array}{l}\text { Partisipasi aktif/ } \\
\text { Active participation }\end{array}$ & $\begin{array}{l}\text { Praktik pengelolaan sumber } \\
\text { daya perikanan harus } \\
\text { melibatkan seluruh anggota } \\
\text { masyarakat termasuk } \\
\text { pemerintah setempat/ } \\
\text { Resource management must } \\
\text { include all stakeholders } \\
\text { including local government. }\end{array}$ & 0.25 & 0.75 \\
\hline & \multicolumn{3}{|c|}{ Nilai kriteria/Criteria value } & 0.25 & 0.75 \\
\hline
\end{tabular}

Sumber: Wawancara prajuru adat dan nelayan/Source: interview on adat leaders and fishers.

\section{Persepsi dan Pemahaman pada Alat dan Teknologi Penangkapan}

Masyarakat nelayan di wilayah tersebut telah mampu mengidentifikasi alat serta teknologi penangkapan yang berpotensi merusak lingkungan maupun sumber daya perikanan yang ada (nilai $0,75)$. Hal ini dipahami dengan baik walau sebagian kecil nelayan mengikuti untuk menghindari sanksi dan bukan karena ingin menjaga lingkungan. Namun demikian, mereka kurang memahami bagaimana mencegah by catch untuk jenis spesies yang dilindungi (nilai 0,27 ). Oleh sebab itu, mereka memilih untuk tidak menaikkannya ke atas kapal dan melepaskannya kembali ke laut dalam kondisi apa pun. Adapun prajuru adat walaupun telah memahami pentingnya pencegahan by catch atau biota hasil tangkapan sampingan yang dilindungi namun belum secara sempurna memahami pencegahan discard atau hasil tangkapan yang terbuang pada saat proses penangkapan (nilai 0,45). Oleh sebab itu, nilai kriteria keduanya tergolong pada kearifan moderat.
Nilai tingkat capaian kriteria alat tangkap dan teknologi pada aspek factual knowledgetertera pada Tabel 8.

Persepsi dan Pemahaman Pada Sosial dan Ekonomi Serta Kesesuaiannya Dengan Tolok Ukur yang Telah Disusun

Hasil pada kriteria sosial dan ekonomi, aspek factual knowledge tolok ukur pengelolaan perikanan yang berkelanjutan baik anggota masyarakat maupun prajuru desa telah memiliki pemahaman yang baik pada indikator kebermanfaatan sumber daya. Nilai parameter yang diperoleh pada anggota masyarakat adalah 0,83 dan nilai pada prajuru desa ialah 0,90 . Hal ini menunjukkan pemahaman sebagian besar dari masyarakat telah menerima manfaat dari sumber daya yang ada. Hal ini juga berimplikasi pada pemahaman yang baik pada indikator pencegahan konflik melalui pengaturan yang ada masyarakat telah memahami dan menilai bahwa penerimaan manfaat telah terdistribusi dengan baik sehingga mampu

Tabel 8. Nilai Capaian Kriteria Alat dan Teknologi Penangkapan Pada Aspek Factual Knowledge. Table 8. Value for Fishing Gear and Technology Criteria on Factual Knowledge.

\begin{tabular}{|c|c|c|c|c|c|}
\hline $\begin{array}{l}\text { Kriteria/ } \\
\text { Criteria }\end{array}$ & Sub & $\begin{array}{l}\text { Indikator/ } \\
\text { Indicators }\end{array}$ & $\begin{array}{l}\text { Parameterl } \\
\text { Parameter }\end{array}$ & $\begin{array}{l}\text { Nilai Nelayan/ } \\
\text { Value Fishers }\end{array}$ & $\begin{array}{l}\text { Nilai Prajuru } \\
\text { Desa/ Value } \\
\text { Adat Leaders }\end{array}$ \\
\hline \multirow[t]{3}{*}{$\begin{array}{l}\text { Alat \& teknologi } \\
\text { penangkapan/ } \\
\text { Capture tools \& } \\
\text { technology }\end{array}$} & $a$ & $\begin{array}{l}\text { Penerapan alat } \\
\text { tangkap legal/ } \\
\text { Use of legal } \\
\text { fishing gear }\end{array}$ & $\begin{array}{l}\text { Penerapan aturan pemerintah } \\
\text { tentang alat tangkap maupun aturan } \\
\text { penangkapan/Implementation of } \\
\text { government regulations }\end{array}$ & 0.75 & 0.85 \\
\hline & $b$ & $\begin{array}{l}\text { Pencegahan by } \\
\text { catch/Avoid by- } \\
\text { catch }\end{array}$ & $\begin{array}{l}\text { Tindakan penanganan untuk } \\
\text { mencegah discard atau by catch/ } \\
\text { Discard or by-catch prevention }\end{array}$ & 0.27 & 0.45 \\
\hline & \multicolumn{3}{|c|}{ Nilai kriteria/Criteria value } & 0.51 & 0.65 \\
\hline
\end{tabular}

Sumber: Wawancara prajuru adat dan nelayan/Source: interview on adat leaders and fishers. 
meminimalkan konflik hal ini tercermin pada nilai parameter 0.71 pada anggota masyarakat dan 0.80 pada prajuru desa.

Tingkat pemahaman yang sama antara anggota masyarakat dan prajuru desa juga terdapat pada indikator benefit proses konservasi baik anggota masyarakat maupun prajuru desa telah memahami pentingnya konservasi namun belum memahami keuntungan lanjutan yang akan didapat. Anggapan yang ada pada keduanya adalah benefit instan berupa lingkungan yang terjaga akan mendatangkan kenyamanan dan belum secara pada pemahaman kelestarian sumber daya. Pada kriteria sosial dan ekonomi, aspek factual knowledge tolok ukur pengelolaan perikanan yang berkelanjutan, nilai kriteria kedua kelompok responden tergolong pada kategori kearifan kuat. Nilai capaian kriteria sosial dan ekonomi pada aspek factual knowledge disajikan pada Tabel 9.

\section{Kriteria Aspek Factual Knowledge dan Hasil Pengukuran Tingkat Kearifan}

Sintesis yang dilakukan terhadap definisi Baltes dan Straudinger (2000) mengenai kearifan dengan berbagai indikator pengelolaan perikanan berkelanjutan yang direkomendasikan oleh Garcia (1996) dan FAO (1995) telah menghasilkan satu tolok ukur kriteria kearifan dalam mengelola sumber daya perikanan. Tolok ukur yang dikembangkan untuk menilai tingkat kearifan masyarakat hukum adat/tradisional pada aspek persepsi dan pemahaman (factual knowledge) tersebut menggunakan lima kriteria dengan beberapa parameter. Pengujian tolok ukur tersebut terhadap kelompok nelayan dan kelompok prajuru desa adat Kedonganan berhasil mengungkapkan tingkat persepsi dan pemahaman mereka terhadap berbagai parameter pengelolaan perikanan berkelanjutan (Tabel 10).

Terungkap bahwa tingkat kearifan nelayan berada pada kategori lemah di kriteria sumber daya dan ekosistem, perencanaan dan tata kelola, serta kelembagaan. Kategori moderat pada kriteria alat tangkap dan teknologi serta tergolong kuat pada kriteria sosial dan ekonomi. Adapun para prajuru desa menunjukkan nilai cenderung moderat sampai kuat di empat kriteria dan hanya satu kriteria sumber daya dan ekosistem yang bernilai lemah.

\section{Praktik Lokal Pengelolaan Sumber Daya Perikanan Masyarakat Adat Desa Kedonganan}

Pengukuran tingkat kearifan praktik lokal pengelolaan sumber daya perikanan mencakup hal yang berkaitan dengan tindakan atau langkah strategis yang dilakukan masyarakat di Desa Adat Kedonganan (procedural knowledge) terhadap lima aspek yaitu: 1)sumber daya dan ekosistem; 2) perencanaan dan tata kelola; 3) Kelembagaan; 4) Alat tangkap dan teknologi; 5) Sosial dan Ekonomi.

\section{Praktik Terkait Sumber Daya dan Ekosistem}

Prajuru Desa Adat Kedonganan tidak menetapkan kawasan perikanan tertentu atau melarang penangkapan ikan pada waktu tertentu, di area tertentu, ataupun untuk spesies tertentu. Kegiatan menangkap ikan hanya berhenti saat kegiatan atau hari-hari besar keagamaan. Desa Adat Kedonganan tidak memiliki sistem untuk

Tabel 9. Nilai Capaian Kriteria Sosial dan Ekonomi Pada Aspek Factual Knowledge. Table 9. Value for Social and Governance Criteria on Factual Knowledge.

\begin{tabular}{|c|c|c|c|c|c|}
\hline $\begin{array}{l}\text { Kriteria/ } \\
\text { Criteria }\end{array}$ & Sub & $\begin{array}{l}\text { Indikatorl } \\
\text { Indicators }\end{array}$ & $\begin{array}{l}\text { Parameterl } \\
\text { Parameter }\end{array}$ & $\begin{array}{l}\text { Nilai Nelayan/ } \\
\text { Value Fishers }\end{array}$ & $\begin{array}{c}\text { Nilai Prajuru } \\
\text { Desa/Adat } \\
\text { Leaders }\end{array}$ \\
\hline \multirow[t]{3}{*}{$\begin{array}{l}\text { Sosial \& } \\
\text { ekonomi/ Social } \\
\text { \& economic }\end{array}$} & $a$ & $\begin{array}{l}\text { Kebermanfaatan } \\
\text { sumber daya/ } \\
\text { Resource benefit }\end{array}$ & $\begin{array}{l}\text { Memperoleh manfaat atas sumber } \\
\text { daya Perikanan/Benefit from } \\
\text { resources }\end{array}$ & 0.83 & 0.90 \\
\hline & $b$ & $\begin{array}{l}\text { Manfaat proses } \\
\text { konservasi// } \\
\text { Conservation } \\
\text { benefit }\end{array}$ & $\begin{array}{l}\text { Proses konservasi atau } \\
\text { penjagaan sumber daya ikan akan } \\
\text { menghasilkan keuntungan ekonomis } \\
\text { kelak/Future benefit from resource } \\
\text { conservation or protection }\end{array}$ & 0.63 & 0.65 \\
\hline & $c$ & $\begin{array}{l}\text { Pencegahan konflik/ } \\
\text { Conflict prevention }\end{array}$ & $\begin{array}{l}\text { Upaya meminimalkan konflik/ } \\
\text { Conflict resolution effort }\end{array}$ & 0.71 & 0.80 \\
\hline & & Nilai kriteria & Criteria value & 0.72 & 0.81 \\
\hline
\end{tabular}

Sumber: Wawancara prajuru adat dan nelayan/Source: interview on adat leaders and fishers. 
Tabel 10. Penilaian Kriteria Aspek Faktual Knowledge Terhadap Kategori Kearifan. Table 10. Evaluation on Factual Knowledge Criterias for Wisdom Category.

\begin{tabular}{|c|c|c|c|c|}
\hline \multirow{2}{*}{$\begin{array}{l}\text { Kriteria/Criteria } \\
\text { Sumber daya dan ekosistem/ } \\
\text { Resources and ecosystem }\end{array}$} & \multicolumn{2}{|c|}{$\begin{array}{l}\text { Nilai dan Status Nelayan/ } \\
\text { Value and Status Fishers }\end{array}$} & \multicolumn{2}{|c|}{$\begin{array}{l}\text { Nilai dan Status Prajuru Desa/ } \\
\text { Value and Status Adat Leaders }\end{array}$} \\
\hline & 0.35 & Lemah/Weak & 0.41 & Lemah/Weak \\
\hline $\begin{array}{l}\text { Perencanaan dan tata kelola/ } \\
\text { Planning and governance }\end{array}$ & 0.42 & Lemah/Weak & 0.67 & Moderat/Moderate \\
\hline Kelembagaan/Institution & 0.25 & Lemah/Weak & 0.75 & Kuat/Strong \\
\hline $\begin{array}{l}\text { Alat tangkap dan teknologi/ } \\
\text { Fishing gear and technology }\end{array}$ & 0.51 & Moderat/Moderate & 0.67 & Moderat/Moderate \\
\hline $\begin{array}{l}\text { Sosial dan Ekonomi/ } \\
\text { Social and economy }\end{array}$ & 0.72 & Kuat/Strong & 0.81 & Kuat/Strong \\
\hline
\end{tabular}

Sumber: Wawancara prajuru adat dan nelayan/Source: interview on adat leaders and fishers.

memantau operasi penangkapan ikan. Adapun pencatatan hasil tangkapan dilakukan oleh pengepul bakul atau petugas di Pangkalan Pendaratan Ikan Kedonganan, namun mereka memiliki perarem awig-awig desa yang melarang nelayan maupun pelaku pariwisata setempat untuk membuang limbah maupun sampah di kawasan pantai Kedonganan. Hal tersebut dijalankan cukup efektif oleh Badan Pengawas Kawasan Pesisir Pantai Kedonganan (BPKP2K) yang diarahkan langsung oleh jero bendesa Desa Adat Kedonganan, walaupun observasi di lapangan menunjukkan bahwa nelayan masih melakukan aktifitas yang dapat mencemari kawasan Pesisir Kedonganan seperti, membuang sisa ikan, mencuci peralatan dan keranjang penampung ikan di pantai. Nilai capaian untuk tiap parameter serta hasil agregat keseluruhan dari kriteria sumber daya dan lingkungan hidup pada aspek procedureal knowledge disajikan pada Tabel 11, dimana terlihat nelayan berada pada tingkat kearifan lemah, sedangkan prajuru desa berada pada tingkat kearifan moderat.

Tabel 11. Nilai Capaian Kriteria Ekosistem dan Sumber Daya Pada Aspek Procedural Knowledge. Table 11. Value for Resource and Ecosystem on Procedural Knowledge.

\begin{tabular}{|c|c|c|c|c|c|}
\hline $\begin{array}{l}\text { Kriteria/ } \\
\text { Criteria }\end{array}$ & Sub & $\begin{array}{l}\text { Indikator/ } \\
\text { Indicators }\end{array}$ & Parameter/Parameter & $\begin{array}{l}\text { Nilai } \\
\text { Nelayan/ } \\
\text { Value } \\
\text { Fishers }\end{array}$ & $\begin{array}{l}\text { Nilai Prajuru } \\
\text { Desa } \\
\text { Values Adat } \\
\text { leaders }\end{array}$ \\
\hline \multirow[t]{4}{*}{$\begin{array}{l}\text { Sumber daya } \\
\text { \& Ekosistem/ } \\
\text { ecosystem } \\
\text { and resource }\end{array}$} & $a$ & $\begin{array}{l}\text { Area konservasi } \\
\text { berbasis ilmiah/ } \\
\text { scientific based } \\
\text { conservation } \\
\text { area }\end{array}$ & $\begin{array}{l}\text { Pembentukan kawasan atau waktu larang tangkap } \\
\text { pada waktu, area, habitat atau spesies tertentu } \\
\text { di daerah pemanfaatan disertai justifikasi ilmiah } \\
\text { yang memadai/Science was used to determine } \\
\text { conservation area, no take zone, prohibited } \\
\text { species. }\end{array}$ & 0.00 & 0.00 \\
\hline & $b$ & $\begin{array}{l}\text { Pemantauan } \\
\text { upaya } \\
\text { penangkapan/ } \\
\text { fishing monitor }\end{array}$ & $\begin{array}{l}\text { Pembentukan sistem pemantauan upaya } \\
\text { penangkapan/Fishing monitoring effort }\end{array}$ & 0.12 & 0.20 \\
\hline & c & $\begin{array}{l}\text { Pencegahan } \\
\text { antropogenik/ } \\
\text { anthropogenic } \\
\text { control }\end{array}$ & $\begin{array}{l}\text { Pelarangan pembuangan sampah, limbah atau } \\
\text { bahan pencemar di sekitar/Pollution control }\end{array}$ & 0.90 & 0.90 \\
\hline & $d$ & $\begin{array}{l}\text { Perizinan khusus } \\
\text { wilayah kritis }\end{array}$ & $\begin{array}{l}\text { Pelarangan atau izin khusus pada pemanfaatan } \\
\text { tanaman bakau, lamun atau terumbu karang/ } \\
\text { Prohibition or special permits on the use of } \\
\text { mangroves, seagrass or coral reefs }\end{array}$ & 0.71 & 0.90 \\
\hline
\end{tabular}

Sumber: Wawancara prajuru adat dan nelayan/Source: interview on adat leaders and fishers. 


\section{Praktik Terkait Perencanaan dan Tata Kelola}

Tidak ada perencanaan ataupun pengaturan tertentu terhadap sumber daya ikan selain peraturan adat yang tidak tertulis terkait kebersihan lingkungan dan tidak melaut pada hari-hari keagamaan. Demikian pula terkait dengan pencatatan hasil tangkapan ataupun pembagian zona tangkapan. Kesemuanya berjalan sebagaimana sudah terbiasa dilakukan selama ini, tanpa ada latar belakang pemikiran untuk mengembangkan pengelolaan sumber daya sesuai dengan sudut pandang pengelolaan yang baik dari Code of Conduct for Responsible Fisheries (1995). Pada praktiknya, prajuru adat Desa Adat Kedonganan menetapkan berbagai peraturan berlandaskan kepercayaan yang mereka anut. Oleh karena itu, masyarakat percaya akan datangnya bala atau musibah bila melanggar peraturan adat yang telah ditetapkan, namun informasi yang diberikan oleh bendesa adat menunjukkan bahwa sebagian masyarakat yang bukan keturunan asli Bali belum sepenuhnya menerima atau melaksanakan peraturan tersebut karena memiliki dasar keyakinan yang berbeda.

Secara kuantitatif capaian nilai kearifan masyarakat Desa Kedonganan tertera di Tabel 12. Nampak dalam tabel tersebut indikator kesetaraan hak dalam pemanfaatan mencapai nilai tinggi
$(0,69$ dan 0,80$)$, dimana prajuru desanya telah memastikan agar semua pihak dapat merasakan manfaat dari sistem pengelolaan yang ada. Berdasarkan keseluruhan parameter yang diuji, kelompok masyarakat nelayan masih tidak teridentifikasi arif sedangkan kelompok prajuru desa tergolong pada kearifan yang lemah.

\section{Praktik Terkait Kelembagaan}

Desa Adat Kedongan memiliki lima kelompok nelayan yang berfungsi sebagai penghubung antara nelayan pemilik dan nelayan buruh serta sebagai wadah dalam penyaluran bantuan bila terdapat program bantuan dari pemerintah. Tiap kelompok memiliki ketua yang mewakili anggotanya saat berdiskusi atau berkoordinasi dengan ketua pasar adat Desa Adat Kedonganan. Ketua pasar adat berwenang menangani hal-hal yang berkaitan dengan perikanan sekaligus menangani pengelolaan pasar adat di desa tersebut.

Secara khusus ketua urusan perikanan dan pasar adat menjadi pelaksana yang mengatur penerapan pengaturan yang ada serta mengkomunikasikan dan memastikan kelompok nelayan melaksanakan hal tersebut. Keseluruhan pelaksanaan pengaturan yang ada di Desa Adat Kedonganan baik menurut prajuru desa adat serta masyarakatnya telah dijalankan dengan transparansi yang baik. Berdasarkan paparan

Tabel 12. Nilai Capaian Kriteria Perencanaan dan Tata Kelola pada Aspek Procedural Knowledge. Tabel 12. Value for Planning and Governance on Procedural Knowledge.

\begin{tabular}{|c|c|c|c|c|c|}
\hline $\begin{array}{c}\text { Kriteria/ } \\
\text { Criteria }\end{array}$ & Sub & Indikator/Indicators & Parameter/Parameter & $\begin{array}{l}\text { Nilai Nelayan/ } \\
\text { Value Fishers }\end{array}$ & $\begin{array}{c}\text { Nilai Prajuru } \\
\text { Desa/Value } \\
\text { Adat Leaders }\end{array}$ \\
\hline \multirow[t]{6}{*}{$\begin{array}{l}\text { Perencanaan } \\
\text { \& Tata kelola/ } \\
\text { Planning \& } \\
\text { governance }\end{array}$} & a & $\begin{array}{l}\text { Penentuan ruang } \\
\text { lingkup pengelolaan/ } \\
\text { Defined management } \\
\text { scope }\end{array}$ & $\begin{array}{l}\text { Pendefinisian rencana aksi } \\
\text { serta batasan dan manajemen } \\
\text { pengelolaan sumber daya ikan/ } \\
\text { Management scope and action plan } \\
\text { defined }\end{array}$ & 0.12 & 0.30 \\
\hline & $\mathrm{b}$ & $\begin{array}{l}\text { Sistem pengawasan/ } \\
\text { Surveillance system }\end{array}$ & $\begin{array}{l}\text { Pembentukan mekanisme untuk } \\
\text { pengawasan, pengendalian dan } \\
\text { evaluasi/Development of control and } \\
\text { surveillance and evaluation }\end{array}$ & 0.12 & 0.20 \\
\hline & c & $\begin{array}{l}\text { Kesetaraan hak dalam } \\
\text { pemanfaatan/ } \\
\text { Inclusive access rights }\end{array}$ & $\begin{array}{l}\text { Pertimbangan hak dan kesetaraan } \\
\text { akses dalam upaya penangkapan/ } \\
\text { Inclusive rights for fishing }\end{array}$ & 0.69 & 0.80 \\
\hline & d & Riset/Research & $\begin{array}{l}\text { penelitian mengenai sumber daya, } \\
\text { upaya serta kapasitas penangkapan } \\
\text { perikanan/Research on resources, } \\
\text { fishing effort and capacity }\end{array}$ & 0.00 & 0.00 \\
\hline & e & $\begin{array}{l}\text { Pendataan dan } \\
\text { pengorganisasian } \\
\text { hasil tangkapan/Data } \\
\text { collection and statistics }\end{array}$ & $\begin{array}{l}\text { data statistik tata kelola serta } \\
\text { organisir hasil tangkapan/Catch } \\
\text { statistics and governance }\end{array}$ & 0.27 & 0.50 \\
\hline & \multicolumn{3}{|c|}{ Nilai kriteria/Criteria value } & 0.24 & 0.36 \\
\hline
\end{tabular}

Sumber: Wawancara prajuru adat dan nelayan/Source: interview on adat leaders and fishers. 
tersebut maka tingkat capaian pada kriteria kelembagaan aspek procedural knowledge terhadap tolok ukur perikanan yang berkelanjutan disajikan berikut pada Tabel 13 .

Nilai yang rendah terdapat pada nilai parameter partisipasi aktif pada kelompok masyarakat nelayan yaitu sebesar 0,12. Hal ini didapat karena sebagian besar masyarakat nelayan hanya mengikuti saja hal-hal yang ditetapkan oleh prajuru desa adat sehingga tidak berpendapat bahwa perlu berpartisipasi dalam menentukan berbagai aturan tersebut. Adapun Prajuru adat berpendapat partisipasi dari berbagai pihak telah cukup terwakili oleh beberapa pihak tertentu seperti juragan pemilik kapal, kulak serta ketua kelompok nelayan. Pada kriteria ini berdasarkan pada penggolongan yang ada, nilai kriteria yang didapat termasuk kedalam kearifan lemah pada kelompok anggota masyarakat dan kearifan moderat pada prajuru desa adat.

\section{Praktik Terkait Alat Tangkap dan Teknologi Penangkapan}

Sebagian besar nelayan telah memahami pentingnya alat tangkap dan teknologi penangkapan yang ramah lingkungan. Mereka juga telah mengikuti regulasi yang ditetapkan oleh pemerintah seperti larangan penggunaan bom, bahan kimia dan racun serta aturan lainya seperti jenis-jenis alat tangkap yang dilarang beroperasi. Namun demikian, sampai saat ini tidak ada aturan atau batasan yang mengatur jumlah armada yang boleh beroperasi. Hal ini menimbulkan peluang penambahan armada baru setiap saat dan meningkatnya upaya tangkapan. Ketiadaan batasan pada jumlah upaya atau armada penangkapan dikhawatirkan dapat merusak sumber daya ikan yang ada.

Hasil tangkapan sampingan atau by catch telah berusaha diminimalkan dengan baik terutama pada biota yang dilindungi Hal ini terjadi karena adanya sosialisasi dari pihak Pangkalan Pendaratan Ikan Kedonganan dalam koordinasinya dengan pasar adat sehingga biota yang dilarang untuk ditangkap tidak dapat dijual belikan di kawasan Pasar Adat Kedonganan. Selain itu, penerapan larangan menangkap biota dilindungi juga ikut diawasi oleh Pangkalan Pengawasan Sumber Daya Kelautan dan Perikanan yang berada di Pangkalan Pendaratan Ikan Kedonganan. Nelayan juga telah berusaha untuk meminimalkan hasil tangkapan yang terbuang melalui pemanfaatan ikan rucah hasil tangkapan atau ikan lain yang berkualitas rendah untuk dikirim ke daerah Pengambengan Bali lalu kemudian dijadikan tepung ikan, namun berdasarkan pengamatan yang ada masih terdapat ikan hasil tangkapan yang terbuang. Tingkat capaian kelompok nelayan dan prajuru adat untuk tiap parameter pada kriteria alat tangkap dan teknologi penangkapan di aspek procedural knowledge dapat dilihat pada Tabel 14. Secara keseluruhan keduanya tergolong pada kearifan moderat.

\section{Praktik Terkait Sosial dan Ekonomi}

Prajuru desa adat maupun nelayan setempat telah memahami bahwa pengelolaan yang ada saat telah meminimalkan konflik antar nelayan maupun konflik nelayan dengan pelaku pariwisata

Tabel 13. Nilai Capaian Kriteria Kelembagaan pada Aspek Procedural Knowledge.

Table 13. Value for Institution on Procedural Knowledge.

\begin{tabular}{|c|c|c|c|c|c|}
\hline Kriteria/Criteria & Sub & $\begin{array}{l}\text { Indikator/ } \\
\text { Indicators }\end{array}$ & $\begin{array}{l}\text { Parameterl } \\
\text { Parameter }\end{array}$ & $\begin{array}{l}\text { Nilai Nelayan/ } \\
\text { Value Fishers }\end{array}$ & $\begin{array}{c}\text { Nilai Prajuru } \\
\text { Desa/Value } \\
\text { Adat Leaders }\end{array}$ \\
\hline \multirow[t]{4}{*}{$\begin{array}{l}\text { Kelembagaan } \\
\text { /Institution }\end{array}$} & $a$ & $\begin{array}{l}\text { Otoritas } \\
\text { manajemen/ } \\
\text { management } \\
\text { authority }\end{array}$ & $\begin{array}{l}\text { penerapan dan otoritas manajemen } \\
\text { yang terstruktur dengan baik/well } \\
\text { structured management authority and } \\
\text { implementation }\end{array}$ & 0.50 & 0.50 \\
\hline & $b$ & $\begin{array}{l}\text { Transparansi } \\
\text { pengelolaan/ } \\
\text { management } \\
\text { transparancy }\end{array}$ & $\begin{array}{l}\text { Transparansi pengelolaan dan } \\
\text { pengambilan keputusan/transparancy } \\
\text { on management and decision making }\end{array}$ & 0.65 & 0.80 \\
\hline & c & $\begin{array}{l}\text { Partisipasi aktif/ } \\
\text { active participation }\end{array}$ & $\begin{array}{l}\text { Penetapan tujuan pengelolaan } \\
\text { berdasakan proses partisipatif/ } \\
\text { management objective based on } \\
\text { participatory process }\end{array}$ & 0.12 & 0.80 \\
\hline & \multicolumn{3}{|c|}{ Nilai Kriteria/Criteria value } & 0.42 & 0.70 \\
\hline
\end{tabular}

Sumber: Wawancara prajuru adat dan nelayan/Source: interview on adat leaders and fishers. 
Tabel 14. Nilai Kesesuaian Kriteria Alat Tangkap dan Teknologi Penangkapan pada Aspek Procedural Knowledge.

Table 14. Value For Fishing Gear and Technology on Procedural Knowledge.

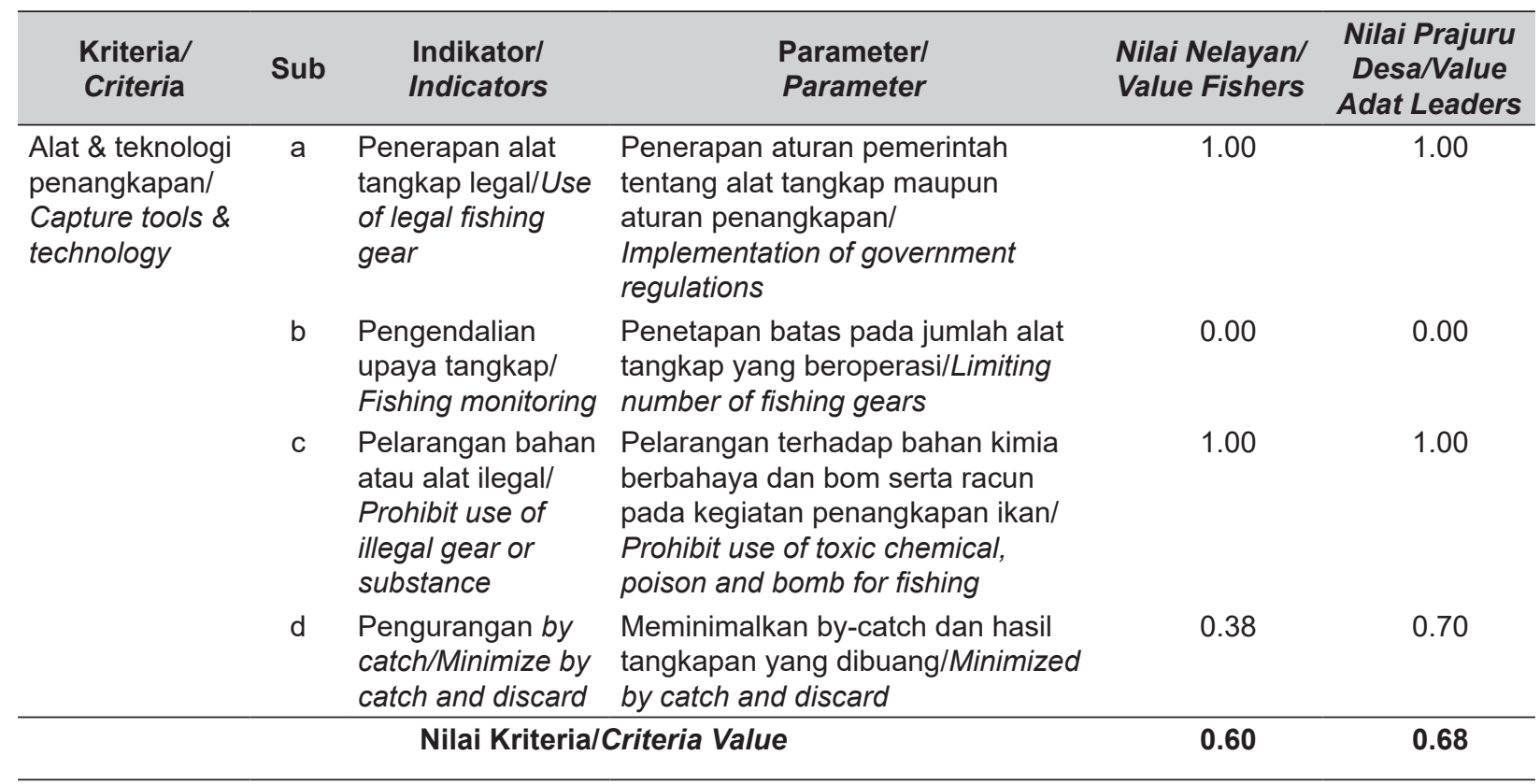

Sumber: Wawancara prajuru adat dan nelayan/Source: interview on adat leaders and fishers.

di wilayah pesisir Desa Adat Kedonganan. Aturan adat tidak tertulis yang membagi daerah tangkapan sesuai dengan ukuran kapal maupun alat tangkap serta zonasi tata letak pada kawasan pariwisata atau kedai-kedai serta restoran serta kawasan perikanan/pemukiman nelayan dan wilayah pasar adat dinilai mampu mencegah konflik tersebut.

Pengaturan tersebut juga dinilai telah mendorong berkembangnya kegiatan ekonomi dan pariwisata yang ada di Desa Adat Kedonganan. Fokus pengembangan pariwisata pesisir ikut berdampak serta memberikan pengaruh yang positif pada pengelolaan perikanan yang ada. Hal ini terjadi karena sebagian besar hasil tangkapan yang ada di nelayan dapat disalurkan dengan baik ke wilayah lain maupun di Desa Adat Kedonganan itu sendiri yang saat ini terdapat banyak kedai yang menjual menu hidangan laut serta olahan ikan. Namun, saat hasil tangkapan melimpah harga ikan di pasar menurun. Hal ini mengundang ketidakpuasan bagi nelayan karena belum ada upaya prajuru desa adat untuk menangani hal tersebut. Oleh sebab itu, nilai capaian seluruh parameter pada kriteria sosial dan ekonomi menunjukkan bahwa nilai kearifan nelayan dan prajuru desa termasuk kategori kearifan kuat (Tabel 15)

Tabel 15. Nilai Capaian Kriteria Sosial dan Ekonomi pada Aspek Procedural Knowledge.

Table 15. Value for Social Economy on Procedural Knowledge.

\begin{tabular}{|c|c|c|c|c|c|}
\hline $\begin{array}{l}\text { Kriteria/ } \\
\text { Criteria }\end{array}$ & Sub & $\begin{array}{l}\text { Indikator/ } \\
\text { Indicators }\end{array}$ & $\begin{array}{l}\text { Parameterl } \\
\text { Parameter }\end{array}$ & $\begin{array}{l}\text { Nilai Nelayan/ } \\
\text { Fishers Value }\end{array}$ & $\begin{array}{c}\text { Nilai Prajuru } \\
\text { Desa/Value Adat } \\
\text { Leaders }\end{array}$ \\
\hline \multirow[t]{2}{*}{$\begin{array}{l}\text { Sosial \& ekonomi/ } \\
\text { Social \& economy }\end{array}$} & $a$ & $\begin{array}{l}\text { Penanganan } \\
\text { konflik/Conflict } \\
\text { resolution }\end{array}$ & $\begin{array}{l}\text { Konflik komunitas pada } \\
\text { praktik pengelolaan/ } \\
\text { Conflict resolution }\end{array}$ & 1.00 & 1.00 \\
\hline & b & $\begin{array}{l}\text { Perkembangan } \\
\text { ekonomi/Economic } \\
\text { development }\end{array}$ & $\begin{array}{l}\text { kegiatan ekonomi sektor } \\
\text { perdagangan maupun } \\
\text { sektor pariwisata/ } \\
\text { Economic activities on } \\
\text { trade and tourism }\end{array}$ & 0.62 & 0.90 \\
\hline \multicolumn{4}{|c|}{ Nilai Kriteria/Criteria Value } & 0.81 & 0.95 \\
\hline
\end{tabular}

Sumber: Wawancara prajuru adat dan nelayan/Source: interview on adat leaders and fishers. 
Adapun fokus pengembangan desa adat saat ini adalah sektor pariwisata dan bukan pada sektor perikanan. Harga ikan yang berfluktuasi hingga pada titik yang rendah terutama pada saat musim ikan melimpah juga menjadi kendala dalam sisi ekonomi menurut nelayan.

Terungkap bahwa tingkat kearifan nelayan berada pada kategori lemah di kriteria sumber daya dan ekosistem, perencanaan dan tata kelola, serta kelembagaan. Kategori moderat pada kriteria alat tangkap dan teknologi serta tergolong kuat pada kriteria sosial dan ekonomi. Adapun para prajuru desa menunjukkan nilai cenderung moderat sampai kuat di empat kriteria dan hanya satu kriteria sumber daya dan ekosistem yang bernilai lemah.

\section{Kriteria Aspek Procedural Knowledge dan Hasil Pengukuran Tingkat Kearifan}

Bagian kedua dari tolok ukur kearifan masyarakat yang dikembangkan dari hasil sistesa antara definisi nilai kearifan (Baltes dan Straudinger 2000) dengan indikator pengelolaan perikanan berkelanjutan (FAO 1995 dan Garcia 1996) adalah pada aspek prosedur dan tindakan (procedural knowledge). Sebagaimana bagian pertama, tolak ukur pada aspek procedural knowledge juga mengukur lima kriteria dengan beberapa parameter kunci. Pengujian tolok ukur tersebut terhadap kelompok nelayan dan kelompok prajuru desa adat Kedonganan berhasil mengungkapkan prosedur dan tindakan yang diterapkan dalam melaksanakan pengelolaan perikanan (Tabel 16).

Terungkap bahwa pada kriteria sumber daya dan ekosistem, masyarakat nelayan maupun prajuru desa tingkat kearifannya lemah. Bahkan, pada kriteria perencanaan dan tata kelola, nelayan tergolong tidak memiliki kearifan yang cukup untuk bisa teridentifikasi. Keberlanjutan sumber daya untuk saat ini masih berpeluang untuk dicapai karena nelayan dan prajuru desa memiliki tingkat kearifan yang cukup/moderat pada kriterai alat tangkap dan technologi. Hal ini didukung oleh tingkat kearifan yang moderat pada prajuru desa yang berfungsi sebagai panutan. Tantangan untuk meningkatkan kearifan dapat terkendala justru karena nelayan dan prajuru desa merasa bahwa capaian sosial dan ekonomi sudah cukup memuaskan.

\section{IMPLIKASI KEBIJAKAN}

Rumusan perangkat tolok ukur tingkat kearifan masyarakat lokal dalam melakukan praktik pengelolaan sumber daya perikanan membuka peluang bagi kebijakan untuk mengadopsinya dalam program-program perikanan. Pilihan kriteria ataupun parameter pengukuran yang digunakan dapat disesuaikan dan dikembangkan lebih lanjut sesuai dengan tujuan pengelolaan ataupun konteks pranata dan kondisi sosial masyarakat setempat. Apabila tolok ukur ini diadopsi, maka pemerintah dapat menetapkan dengan terukur berbagai praktik masyarakat lokal ke dalam berbagai kategori tingkat kearifan, sehingga tidak lagi ada kesalahpahaman dimana setiap praktik pengelolaan sumber daya masyarakat lokal otomatis disebut sebagai suatu kearifan. Dengan demikian, pemerintah dapat menyusun program-program penguatan ataupun fasilitasi teknis secara lebih terarah bagi masyarakat lokal maupun masyarakat hukum adat/tradisional agar tingkat kearifan dalam pengelolaan sumber daya perikanan dapat benar-benar mencapai keberlanjutan.

Tabel 16. Penilaian Kriteria Aspek Procedural Knowledge Terhadap Kategori Kearifan. Table 16. Evaluation on Procedural Knowledge Criteria for Wisdom Category.

\begin{tabular}{|c|c|c|c|c|}
\hline \multirow{2}{*}{$\begin{array}{l}\text { Kriteria/Criteria } \\
\text { Sumber daya dan ekosistem/ } \\
\text { Resources and ecosystem }\end{array}$} & \multicolumn{2}{|c|}{$\begin{array}{l}\text { Nilai dan status Nelayan/ } \\
\text { Value and Status Fishers }\end{array}$} & \multicolumn{2}{|c|}{$\begin{array}{l}\text { Nilai dan Status Prajuru Desal } \\
\text { Value and Status Adat Leaders }\end{array}$} \\
\hline & 0.43 & Lemah/Weak & 0.50 & Lemah/Weak \\
\hline $\begin{array}{l}\text { Perencanaan dan tata kelola/ } \\
\text { Planning and governance }\end{array}$ & 0.24 & $\begin{array}{l}\text { Tidak Teridentifikasi Arif/ } \\
\text { Un-wise }\end{array}$ & 0.36 & Lemah/Weak \\
\hline Kelembagaan/Institution & 0.42 & Lemah/Weak & 0.70 & Moderat/Moderate \\
\hline $\begin{array}{l}\text { Alat tangkap dan teknologi/ } \\
\text { Fishing gear and technology }\end{array}$ & 0.60 & Moderat/Moderate & 0.68 & Moderat/Moderate \\
\hline $\begin{array}{l}\text { Sosial dan Ekonomi/Social and } \\
\text { economy }\end{array}$ & 0.81 & Kuat/Strong & 0.95 & Kuat/Strong \\
\hline
\end{tabular}

Sumber: Wawancara prajuru adat dan nelayan/Source: interview on adat leaders and fishers. 
Hasil uji coba menunjukkan adanya perbedaan tingkat kearifan di antara kelompok prajuru adat dengan kelompok nelayan. Pada aspek Dasar Pemikiran tingkat kearifan nelayan merujuk pada kategori lemah di tiga dari lima kriteria. Nelayan mencapai tingkat moderat pada kriteria alat tangkap dan teknologi serta mencapai tingkat tergolong kuat pada kriteria sosial dan ekonomi, sedangkan para prajuru desa menunjukkan nilai cenderung moderat sampai kuat di empat kriteria dan hanya satu kriteria yang bernilai lemah (sumber daya dan ekosistem). Pada aspek Praktik Pengelolaan tidak terdapat perbedaan tingkat kearifan diantara kedua kelompok tersebut. Keduanya cenderung lemah pada kriteria ekosistem dan sumber daya, perencanaan, dan kelembagaan. Kriteria alat tangkap mencapai tingkat moderat, dan tingkat tinggi pada kriteria sosial ekonomi.

Apabila Kementerian Kelautan dan Perikanan tetap mencantumkan Desa Adat Kedonganan sebagai desa dengan kearifan lokal dalam pengelolaan sumber daya, maka perlu memberikan program edukasi yang baik mengenai sumber daya perikanan yang ada, pendampingan dan pembentukan sistem monitoring-controllingsurveilance atau pemantauan pengaturan dan pengawasan berbasis riset dengan mempertimbangkan masukan berkala dari berbagai pihak khususnya anggota masyarakat dalam hal ini nelayan, pendampingan dan pembentukan program pengelolaan partisipatif pada tata kelola perikanan yang ada, pengenalan alat tangkap serta teknologi penangkapan ramah lingkungan dalam upayanya mencegah by catch serta pembatasan jumlah alat tangkap baik secara temporal ataupun spasial berdasarkan jumlah yang ditentukan oleh riset serta kajian ilmiah.

\section{UCAPAN TERIMA KASIH}

Terima kasih penulis ucapkan kepada Darmawan yang memberikan ide, konsep serta membimbing pelaksanaan penelitian, termasuk menyempurnakan naskah ini agar memenuhi syarat publikasi. Demikian pula terhadap Wawan Oktariza yang telah banyak memberi bimbingan dan masukan selama penelitian. Selain itu penulis ucapkan terima kasih kepada kepada I Wayan Mertha sebagai perwakilan Prajuru Desa Adat Kedonganan yang banyak membantu memberikan pemahaman mengenai adat kebiasaan dan informasi penting terkait praktik pengelolaan perikanan, dan $\mathrm{D} N$ Suandika dari pemerintah daerah yang memfasilitasi terlaksananya penelitian ini.

\section{PERNYATAAN KONTRIBUSI PENULIS}

Kontributor dalam karya tulis ilmiah adalah Ari Kurniawan sebagai peneliti dan penulis utama, Darmawan sebagai konseptor penelitian dan meramu penyusunan naskah sehingga memenuhi persyaratan publikasi, dan Wawan Oktariza sebagai kontributor anggota yang sudah disepakati bersama-sama untuk diketahui semua pihak yang berkepentingan.

\section{DAFTAR PUSTAKA}

Aminpour, P., Gray, S.A., Jetter, A.J., Introne, J.E., Singer, A., Arlinghaus, R. (2020). Wisdom of stakeholder crowds in complex social-ecological systems. Nature Sustainability, 1-9. DOI: 10.1038/s41893-019-0467

Ardelt, M. (2004). Wisdom as Expert Knowledge System: A Critical Review of a Contemporary Operationalization of an Ancient Concept. Human Development, 47(5), 257-285. DOI: $10.1159 / 000079154$

Arlinghaus, R., Cooke, S.J., Sutton, S.G., Danylchuk, A.J., Potts, W., Freire, K.De M.F., Alós, J., Da Silva, E.T., Cowx, I.G., and Van Anrooy, R. (2016) Recommendations for the future of recreational fisheries to prepare the social-ecological system to cope with change. Fisheries Management and Ecology, 23 (3-4). pp. 177-186. DOI: https://doi.org/10.1111/fme.12191

Arlinghaus, R., Krause, J. (2013). Wisdom of the crowd and natural resource management. Trends in Ecology \& Evolution, 28, 8-11. DOI: 10.1016/j. tree.2012.10.009

Baltes, P. B., \& Staudinger, U. M. (2000). Wisdom: A metaheuristic (pragmatic) to orchestrate mind and virtue toward excellence. American Psychologist, 55(1), 122-136. DOI: 10.1037/0003066X.55.1.122

Bond, F. W, \& Dryden, W. (2002). Handbook of Brief Cognitive Behaviour Therapy. West Sussex, EN: Jonh Wiley \& Sons Ltd

Creswell, J. W. (2014). Research Design: Qualitative, Quantitative, and Mixed Methods Approaches. 4th ed. Thousand Oaks, CA: SAGE Publications

Damon, W \& Lemer, R.M. (2006). Handbook of Child Psychology Theoretical Models of Human Depelovment. New Jersey, CA: Jonh Wiley \& Sons Ltd

Douglas, E.M. Kenneth M. Reardon, Mathias C. Täger. (2018). Participatory action research as a means of achieving ecological wisdom within climate 
change resiliency planning. Journal of Urban Management, Vol 7(3), 152-160. DOI: 10.1016/j. jum.2018.05.003

Dudley, N., Baldock, D., Nasi, R., Stolton, S. (2005). Measuring biodiversity and sustainable management in forests and agricultural landscapes. Philosophical Transactions of the Royal Society of London, Series B, Biological Sciences 360(1454), 457-470. DOI: 0.1098/ rstb.2004.1953

[FAO] Food Agriculture Organization. (1995). Code of Conduct for Responsible Fisheries. Rome(IT) : Food and Agriculture Organization

Ferrari, M, \& Potworowski, G. (2008). Teaching for Wisdom: Cross-cultural Perspectives on Fostering Wisdom. Burlington, VT: Springer

Fitrisia. A. (2014). Upacara "Tolak Bala" Refleksi Kearifan Lokal Masyarakat Nelayan Kenagarian Painan Kabupaten Pesisir Selatan Propinsi Sumatera Barat terhadap Laut. Jurnal Humanus, 12(1): 51-58. DOI: 10.24036/jh.v13i1.4097

Garcia. S. M. (1996). Indicator for sustainable Development of Fisheries. [Paper 2nd World Fisheries Congress. Workshop on Fisheries Sustainably Indikator].Rome(IT): Food and Agriculture Organization

Gugerell, Stefan H. \& Riffert, F. 2012. On Defining "Wisdom": Baltes, Ardelt, Ryan, and Whitehead. Interchange, Vol. 42(3), 225-259. DOI: 10.1007/ s10780-012-9158-7

Hardin, G. (1968). The Tragedy of Commons. Journal of Science, New Series,162(3859),143-148. Retrieved from: https://www.sciencemag.org/ site/feature/misc/webfeat/sotp/pdfs/1623859-1243.pdf

[KKP] Kementerian Kelautan dan Perikanan. (2017). Penguatan Peran Masyarakat Hukum Adat dalam Pengelolaan Sumber daya Laut di Wilayah Pesisir dan Pulau Pulau Kecil. Materi Paparan Direktur Jenderal Pengelolaan Ruang Laut. Jakarta (ID): Kementerian Perikanan dan Kelautan Republik Indonesia

Likert, R. (1932). A Technique for Measurement of Attitudes. Archives of Psychology, 140, 5-55. Retrieved from: https://psycnet.apa.org/ record/1933-01885-001

Naing, N, Santosa, H. R., \& Soemarno, I. (2009). Kearifan Lokal Tradisional Masyarakat Nelayan pada Permukiman Mengapung di Danau Tempe Sulawesi Selatan. Jurnal Local Wisdom, Vol 1(1), 19-26. Retrieved from: http://jurnal.unmer.ac.id/ index.php/lw/article/view/1362

Neuman, W. I. (2003). Social Research Methods: Qualitative and Quantitative Approaches. Boston, US: Allyn and Bacon
Nikijuluw, V.P.H. (1994). Indigenous Fisheries Resource Management in the Maluku Islands. Journal Indigenous Knowledge and Development Monitor, 2(2), 6-8

Pemerintah Republik Indonesia. (1945). Undang Undang Dasar Republik Indonesia tahun 1945. Jakarta, ID: Pemerintah Republik Indonesia

Pemerintah Republik Indonesia. (2004). Undang-Undang Nomor 31 Tahun 2004 tentang Perikanan. Jakarta, ID: Pemerintah Republik Indonesia

Pemerintah Republik Indonesia. (2014). Undang-Undang Republik Indonesia Nomor 1 Tahun 2014 tentang Perubahan atas Undang-Undang Nomor 27 Tahun 2007 tentang Pengelolaan Wilayah Pesisir dan Pulau-Pulau Kecil. Jakarta, ID: Pemerintah Republik Indonesia

Pusat Bahasa Departemen Pendidikan Nasional. (2008). Kamus Besar Bahasa Indonesia. Jakarta, ID: Departemen Pendidikan Nasional

Puspita, M. (2017). Kearifan Lokal Dalam Pengelolaan Sumber Daya Pesisir Dan Laut Hukum Adat Laot dan Lembaga Panglima Laot di Nanggroe Aceh Darussalam. Sabda: Jurnal Kajian Kebudayaan, 3(2).doi: 10.14710/sabda.3.2.\%p

Sandita, M.Fedi.A. (2012). Manajemen Sumber Daya Perikanan (Edisi 2). Tangerang Selatan, ID: Universitas Terbuka

Suharjito D. (2003). Pengembangan Kapasitas Masyarakat Lokal dan Stake Holder Lain dalam Pembangunan Pengelolaan Hutan Berbasis Masyarakat. [Seminar Pekan IImiah Kehutanan Nasional (PIKNAS) Fakultas Kehutanan IPB]. Bogor, ID: Institut Pertanian Bogor

Zamani, N. P. \& Darmawan, (2000). Pengelolaan Sumber daya Pesisir Terpadu Berbasis Masyarakat. Prosiding Pelatihan untuk Pelatih Pengelolaan Wilayah Pesisir Terpadu Pusat Kajian Sumber daya Pesisir dan Lautan IPB. Retrieved from https://repository.ipb.ac.id/ jspui/bitstream/123456789/25055/1/Prosiding_ pengelolaan_wilayah_pesisir_terpadu-5.pdf 